\title{
MIĘDZY HISTORIĄ, IDEOLOGIĄ I TEOLOGIA.. PRO-DAWIDOWA LEKTURA TRADYCJI O SAULU W PIERWSZEJ KSIĘDZE KRONIK
}

Saul, syna Kisza, to najbardziej znany w Biblii Hebrajskiej przedstawiciel pokolenia Beniamina i pierwszy oficjalny król Izraela (por. 1Sm 9,1 - 10,16 i Sdz 8,22-23; 9,1-57), a zarazem jedna z najbardziej kontrowersyjnych postaci literatury starotestamentowej. Przyczyną kontrowersji, które narosły wokół jego osoby wpierw na etapie redakcji najstarszych źródeł o monarchii w Izraelu (1Sm 7,2 - 12,25; 13,1 -15,35; 16,1 - 2Sm 5,5), a następnie ich późniejszej teologicznej i historycznej reinterpretacji dokonanej przez deuteronomistycznych (Joz-2Krl) i kronikarskich historiografów (1-2Krn), nie był wcale przebieg i tragiczny finał jego politycznej kariery ukazany w 1Sm 9,1 - 31,13. ${ }^{1}$ Znacznie większy wpływ na krytyczny sposób postrzegania Saula przez historiografów biblijnych miały uwarunkowania społeczno-polityczne i koncepcje ideowo-teologiczne, które towarzyszyły dojściu do władzy Dawida (1Sm 16,1 -2Sm 5,5), jego syna - Salomona (2Sm 12,24-25; $1 \mathrm{Krl} 1,1$ - 3,28), a także ukonstytuowaniu się w Izraelu i Judzie dynastii opartej na idei przymierza

1 R. M ü 11 e r, Saul, the Charismatic King: Concepts of Political Leadership in 1Sam 11, w: K. P y s c h n y, S. S c h u 1 z (red.), Debating Authority. Concepts of Leadership in the Pentateuch and the Former Prophets, BZAW 507, de Gruyter, Berlin 2018, s. 262-287; O. K a i s e r, Der historische und der biblische König Saul (Teil I), ZAW 122(2010) nr 4, s. 520-545; t e n ż e, Der historische und der biblische König Saul (Teil II), ZAW 123(1; 2011), s. 1-14; N. N a ' a m a n, Saul, Benjamin and the Emergence of "Biblical Israel" (Part I), ZAW 121(2009) nr 2, s. 211-224; t e n ż e, Saul, Benjamin and the Emergence of "Biblical Israel" (Part II), ZAW 121(2009) nr 3, s. 335-349. 
Dawidowego (2Sm 7,1-29; 22,1-23,7; $1 \mathrm{Krl}$ 2,1-4; 6,12-13; 8,20.25; 9,4-9; Ps $89 ; 132)$. W tym właśnie okresie sprzyjający Dawidowi autorzy stworzyli oryginalne zręby aktualnej biblijnej opowieści o konflikcie domu Saula z domem syna Jessego (2Sm 2,1-4,12; 21,1-14), w której Saul po raz pierwszy został ukazany jako niezrównoważony, nieudolny i nieposłuszny Bogu król, odrzucony przez JHWH, a także elity społeczno-religijne i lud Izraela i Judy (1Sm 16,1-2Sm 5,5).

Na kolejnych etapach edycji przekazów o Saulu i Dawidzie, którym ostateczny kształt nadali pro-Dawidowi redaktorzy stojący za aktualną wersją Pierwszej i Drugiej Księgi Samuela, proces dyskredytacji syna Kisza przyjął formę jeszcze szerzej zakrojonej i konsekwentnie realizowanej elaboracji ideowo-teologicznej. Jej zasadniczym celem była anty-Saulowa relektura oryginalnych źródeł, które utrwaliły pozytywny obraz Saula i rodu Beniamina, akcentując jego wielki wkład w wojnę z Filistynami, ${ }^{2}$ inicjację procesu daleko idących przemian społeczno-politycznych i militarnych w Izraelu (1Sm 13,1-7.15b-14,52), a szczególnie bohaterską walkę i śmierć na wzgórzu Gilboa (31,1-13). I tak pozytywny wizerunek Saula zastąpiono narracją propagującą bardzo krytyczną ocenę pierwszego monarchy Izraela. Kolejni historiografowie, pragnąc uzasadnić przejęcie władzy w Izraelu przez pokolenie Judy i jak najlepiej zaprezentować syna Jessego, postanowili ukazać jego poprzednika w teologicznym kluczu nieposłuszeństwa Bogu i prorokowi.

Ślady pro-Dawidowej relektury źródeł widać już na poziomie przeddeuteronomistycznej redakcji cyklu tradycji o narodzinach monarchii w Izraelu (1Sm 7,2 - 12,25), dojściu Dawida do władzy (1Sm 16,1 - 2Sm 5,5) czy apendyksu do Ksiąg Samuela (2Sm 21,1 24,25). Ten materiał źródłowy o rządach Saula i Dawida (w formie ustnej lub spisanej) przejęli na dalszym etapie redakcji twórcy deuteronomistycznej historiografii (Joz-2Krl), którzy postanowili

2 H. B e z z e 1, Saul und die Philister: Redaktionskritische Überlegungen zu 1 Samuel 13-14, w: W. D i e t r i c h, The Books of Samuel. Stories - History Reception History, BETL 284, Peters, Leuven 2016, s. 457-466. 
w całości i w prawie niezmienionej formie ${ }^{3}$ wprowadzić go w obręb swego dzieła. Z uwagi na społeczno-polityczną predylekcję do Dawida i jego dynastii, deuteronomiści w kluczowych miejscach przejętych cykli tradycji umieścili jedynie passusy, które mocniej akcentowały Boże wybranie syna Jessego (1Sm 16,1-13; 16,14-23; 17,1-58), a zarazem odrzucenie Saula (1Sm 13,8-15a; 15,1-35; 16,13-14; 28,15-19), jego potomków (1Sm 31,6; 2Sm 1,4) i całego rodu Beniamina (2Sm 3,1). W ostatecznej wersji Pierwszej Księgi Samuela klęska

3 W opinii większości współczesnych egzegetów, aktualną strukturę obu Ksiąg Samuela tworzy seria pierwotnie autonomicznych cykli tradycji, z których najstarsze sięgają X w. przed Chr. Choć teksty te noszą na sobie ślady długiego procesu redakcji, to jednak ich zasadniczy kształt literacki i ideowo-teologiczny ukonstytuował się stosunkowo wcześnie. Przekazy o genezie instytucji proroka i króla w Izraelu oraz ich rozwoju w dobie rządów Saula i Dawida noszą na sobie zdecydowanie najmniej śladów elaboracji deuteronomistycznej ze wszystkich ksiąg zaliczanych do zbioru Joz-2Krl. Bloki narracyjne Pierwszej i Drugiej Księgi Samuela charakteryzują się dużą różnorodnością literacką i tematyczną, a także niejednakową perspektywą narracji i oceny zdarzeń, opisując historyczny i historio-zbawczy kontekst narodzin profetyzmu (1Sm 1,1 - 3,21) i monarchii w Izraelu (1Sm 7,1 - 12,25), a nadto genezę kultu Arki JHWH w Jerozolimie (1Sm 4,1 - 7,1; 2Sm 6,1-23), rządy Saula (1Sm 13,1 - 15,35), przejęcie władzy przez Dawida (1Sm 16,1-2Sm 5,5) i jego rządy $(2 \operatorname{Sm} 5,6$ - 10,19; 11,1 - 20,26; 21,1 - p 24,15). Brak wyraźnych śladów teologii deuteronomicznej i deuteronomistycznej w tych cyklach sugeruje, że strukturalne komponenty aktualnej wersji obu Ksiąg Samuela funkcjonowały wcześniej jako rozczłonkowany, ale spójny i zdefiniowany tematycznie materiał literacki. B.T. A r n o ld, Samuel, Books of, w: B.T A r n o ld, H. W ill i a m s o n (red.), Dictionary of the Old Testament. Historical Books, InterVarsity Press, Downers Grove-Nottingham 2005, s. 866-867, 870-872; G.N. K n o p p e r s, The Historical Study of the Monarchy: Developments and Detours, w: D.W. B a k e r, B.T. A r nold (red.), The Face of the Old Testament Studies: A Survey of Contemporary Approaches, Baker, Grand Rapids 1999, s. 207-235; C. N i h a n, D. N o c qu e t, 1-2 Samuel, w: T. Rö m e r, J.D. M a c h i, C. Nihan (red.), Introduction à l'Ancien Testament, MDB 45, Labor et fides, Genève 2004, s. 283-295; J. G e r t z, M. W i t t e, K. S c h m i d (red.), Die deuteronomistischen Geschichtswerke, BZAW 365, de Gruyter, Berlin 2012; C. E d e n b u r g, J., P a k k a 1 a (red.), Is Samuel among the Deuteronomist? Current Views on the Place Samuel in a Deuteronomistic History, SBL 16, Society of Biblical Literature, Atlanta 2013; C. S c h ä fe r - L i c h t e n b e r g e r (red.), Die Samuelbücher und die Deuteronomisten, BWANT 188, Kohlhammer, Stuttgart 2010. 
Saula jest ukazana na wszystkich możliwych płaszczyznach. Pierwszego społeczno-militarnego lidera (nāgîd) i króla (melek) Izraela kolejno odrzucają: Bóg JHWH, elity społeczno-religijne (prorocy Samuel i Gad, starsi ludu), a także najbliższe otocznie i cały lud. ${ }^{4}$

Reasumując tę zwięzłą prezentację historiograficznego formatu Ksiąg Samuela, które stały się głównym źródłem Kronikarza, należy zaznaczyć, że na prawie wszystkich kluczowych etapach redakcji zebranych w nich tradycji rekonstruujących początki monarchii

4 Wielopłaszczyznową analizę egzegetyczno-teologiczną tych źródeł, a szczególnie społeczno-polityczny i religijny kontekst walki o władzę między obozami Saula i Dawida, w różnych ujęciach metodologicznych proponują monografie: R. B a r t e $1 \mathrm{~m} \mathrm{u} \mathrm{s,} \mathrm{Heroentum} \mathrm{in} \mathrm{Israel} \mathrm{und} \mathrm{seiner} \mathrm{Umwelt,} \mathrm{ATANT} \mathrm{65,} \mathrm{Theolo-}$ gischer Verlag, Zürich 1979; U. B e r g e s, Die Verwerfung Sauls. Eine thematische Untersuchung, FzB 61, Echter, Würzburg 1989; H. B e z z e 1, Saul: Israels König in Tradition, Redaktion und früher Rezeption, FAT 1.97, Mohr Siebeck, Tübingen 2015; R. C a r 1 s o n, David the Chosen King. A Traditio-Historical Approach to the Second Book of Samuel, Almqvist \& Wilksell, Stockholm 1964; W. D i e t r i c h, David, Saul und die Propheten. Das Verhältnis von Religion und Politik nach den prophetischen Überlieferungen vom frühesten Königtum in Israel, BWANT 122, Kohlhammer, Stuttgart 1987; F. F o r e s t i, The Rejection of Saul in the Perspective of the Deuteronomistic School. A Study of 1 Sam 15 and Related Texts, STT 5, Edizioni del Teresianum, Rome 1984; T. I s h i d a, The Royal Dynasties in Ancient Israel. A Study on the Formation and Development of Royal-Dynastic Ideology, BZAW 142, de Gruyter, New York 1977; S. N i c h o 1 s o n, Three Faces of Saul. An Intertextual Approach to Biblical Tragedy, JSOT.S 339, Sheffield Academic Press, Sheffield 2002; K. N o 11, The Faces of David, JSOT.S 242, Sheffield Academic Press, Sheffield 1997; T. V e i j o 1 a, Die ewige Dynastie. David und die Entstehung seiner Dynastie nach der deuteronomistischen Darstellung, AASF B 193, Suomalainen Tiedeakatemia, Helsinki 1975; t e n ż e, Das Königtum in der Beurteilung der deuteronomistischen Historiographie. Eine redaktionsgeschichtliche Untersuchung, AASF B 198, Suomalainen Tiedeakatemia, Helsinki 1977; Y. Y o n i c k, Rejection of Saul as King of Israel, Franciscan Printing, Jerusalem 1970; K. A d a m, Saul und David in der judäischen Geschichtsschreibung: Studien zu 1 Samuel 16 - 2 Samuel 5, FAT 51, Mohr Siebeck, Tübingen 2007; W. D i e t r i c h, 1 Samuel 1-12, BKAT 8.1, Neukirchener, Neukirchen-Vluyn 2011; A. He i n r i c h, David und Klio. Historiographische Elemente in der Aufstiegsgeschichte Davids und im Alten Testament, BZAW 401, de Gruyter, Berlin 2009. 
w Izraelu ${ }^{5}$ uwaga redaktorów była niezmiennie zogniskowana na wielorakiej krytyce Saula i pochlebnej ocenie osoby i działań Dawida. Kolejni redaktorzy obu Ksiąg Samuela coraz bardziej nieprzychylnymi dla Saula interpolacjami postanowili stłumić oryginalny ton pierwotnych relacji o synu Kisza, które ukazywały go jako wybrańca JHWH (1Sm 9,15-16) działającego mocą Jego ducha (1Sm 10,7.12-13; 11,12) i realizującego charyzmatyczną misję wyzwolenia Izraela z rąk Filistynów (1Sm 9,16), a także legitymującego się aprobatą ze strony świeckich i religijnych wodzów oraz ludu Izraela (1Sm 8,1-22; 10,17-27; 11.1-15; 12,1-25; 13,1-15,35).

Jeszcze szerszy zakres i bardziej zdecydowane formy wyrazu anty-Saulowa, a zarazem pro-Dawidowa relektura narodzin monarchii w Izraelu przybrała w historiografii przypisywanej środowisku Kronikarza. ${ }^{6}$ Ta kwestia będzie podstawowym problemem badaw-

5 Na bazie analizy pochodzących z różnych środowisk pisarskich przekazów zebranych w obu Księgach Samuela, czyli najstarszych dostępnych dziś źródeł na temat ustanowienia monarchii w Izraelu, które najgłębszymi korzeniami sięgają epoki opisywanych zdarzeń, należy sądzić, że ich pro-Dawidowa, a jednocześnie anty-Saulowa relektura dokonała się na dwu istotnych etapach. Najstarsze źródła o Saulu modelowały go na wzór bohaterskiego sędziego, który z mandatu Bożego walczył o wolność uciśnionych Izraelitów, stworzył podwaliny polityczno-militarne instytucji króla, a nade wszystko oddał życie w obronie narodu. Z czasem te teksty zostały gruntownie przepracowane i uzupełnione o przekazy sprzyjające synowi Jessego. Należy przypuszczać, że ten proces ideowo-teologicznej elaboracji oryginalnych źródeł dokonał się w okresie dojścia do władzy Dawida, a potem Salomona (przełom XI i X w. i pierwsza połowa IX w. przed Chr.) i miał na celu utrwalenie społeczno-politycznej pozycji rodu Judy w konfrontacji o władzę z innymi pokoleniami Izraela (np. rodem Beniamina). Drugim istotnym etapem reinterpretacji Ksiąg Samuela była ich interpolacja w struktury deuteronomistycznej historiografii (Joz-2Krl), która miała miejsce w okresie religijnej reformy Jozjasza (ok. 622 r. przed Chr.) i po niewoli babilońskiej, kiedy próbowano uzasadnić upadek monarchicznych struktur w Izraelu (722 r. przed Chr.) i Judzie (586 r. przed Chr.), a jednocześnie usiłowano ożywić nadzieje mesjańskie i odbudować narodowo-religijną tożsamość ludu wybranego opartą na koncepcji dynastii Dawida i przymierza Dawidowego.

6 D. Ja n ze n, Chronicles and the Politics of Davidic Restoration. A Quiet Revolution, T\&T Clark, Bloomsbury 2017, s. 1-33; T. C u d w or t h, War in Chronicles. Temple Faithfulness and Israel's Place in the Land, Oxford 2014, s. 9-29. 
czym niniejszego artykułu, pogłębianym sukcesywnie w kluczu metody historyczno-krytycznej i intertekstualnej. Głównym celem badań będzie zestawienie wszystkich tradycji o Saulu utrwalonych w Pierwszej Księdze Kronik z wszechobecną w tej księdze pochwałą rządów Dawida. To merytoryczne porównanie tekstów pozwoli na kolejnym etapie badań określić założenia strukturalne i profil ideowo-teologiczny historiografii proponowanej przez Kronikarza, a nade wszystko zdefiniować charakter i zakres anty-Saulowej i pro-Dawidowej lektury opisywanych przez niego zdarzeń.

\section{Literacka i teologiczna specyfika historiografii Kronikarza}

Wyjątkowy charakter kronikarskiej rekonstrukcji początków monarchii w Izraelu wiąże się ze specyficzną genezą i profilem programowym tego dzieła. W przeciwieństwie do innych biblijnych ksiąg historycznych, a szczególnie do Pierwszej i Drugiej Księgi Samuela i Pierwszej i Drugiej Księgi Królewskiej, które stanowią główny rezerwuar informacji dla Kronikarza, materiał narracyjny w Pierwszej i Drugiej Księgi Kronik jest jednolity pod względem formy literackiej, a także wyrazisty i spójny pod kątem proponowanego klucza lektury relacjonowanych treści. Wbrew opinii niektórych egzegetów, ${ }^{7}$ Księgi Kronik nie są midraszem do obu Ksiąg Samuela i Królewskich, ${ }^{8}$ choć noszą pewne znamiona midraszy, które

7 J. We 11 h a u s e n, Prolegomena zur Geschichte Israels, G. Reiner, Berlin 1883, s. 223; t e n ż e, Prolegomena to the History of Ancient Israel, P. Smith, Gloucester 1973, s. 227; I. B e n z i n g e r, Die Bücher der Chronik-erklärt, KHCAT 20, J.C. Mohr, Tübingen 1901, s. XI-XIII; R. K i t t e 1, Die Bücher der Chronik übersetzt und erklärt, GHAT 6.1, Vandenhoeck \& Ruprecht, Göttingen 1902, s. IX; A. W e 1 c h, The Work of the Chronicler: Its Purpose and Its Date, SLBA, Oxford University Press, London 1938, s. 54; M. G r a h a m, The Utilization of 1 and 2 Chronicles in the Reconstruction of Israelite History in the Nineteenth Century, SBLDS 116, Scholars Press, Atlanta 1990, s. 141-150.

Teksty: 2Krn 13,22 (midraš hannābî̀' 'iddô ,historia /opowiadanie, komentarz, midrasz/ proroka Iddo”) i 24,27 (midraš seper hammelākîm „studium /ekspozycja, zapis, traktat, historia, midrasz/ do Księgi Królów”, definiują tak wprawdzie niektóre ze źródeł Kronikarza, ale tego pojęcia nie należy odnosić do całego dzieła. 
w duchu tradycji rabinackiej usiłowały nadawać nowy sens historiozbawczy funkcjonującym w środowisku Izraela tradycjom (źródłom), nie przykładając wagi do ich wiarygodności stricte historycznej. Przypisywanie tym księgom funkcji midraszu jest nieuzasadnione, gdyż pozbawia je, a przynajmniej w dużej mierze redukuje, ich ściśle określoną wartość historyczną, która - uwzględniając standardy ówczesnej historiografii oraz metodologiczne cele i merytoryczne założenia Kronikarza - nie może podlegać żadnej wątpliwości.

Podobnie niepełną i nieadekwatną definicją dzieła Kronikarza jest postulowana przez uczonych koncepcja komentarza egzegetycznego do istniejącego już w jego epoce Pięcioksięgu czy Ksiąg Samuela i Królewskich. Celem tego komentarza byłaby teologiczna reinterpretacja starożytnych źródeł opowiadających o historii Izraela do powrotu z wygnania babilońskiego. ${ }^{9} \mathrm{~W}$ świetle tej koncepcji, Księgi Kronik należałoby zaliczyć do tzw. literatury interpretacyjnej, która z czasem weszła do żydowskiego kanonu ksiąg natchnionych. Ich celem miało być potwierdzenie historio-zbawczej wiarygodności i wagi Proroków wcześniejszych (Joz-2Krl) i klasycznych (więksi i mniejsi), a także aktualizacja ich przesłania w epoce Kronikarza, czyli w pierwszych dziesięcioleciach IV w. przed Chr. ${ }^{10}$ Jednak i ta teoria jest dość krucha. Wystarczy tu przywołać metodologię, z jaką Kronikarz podchodzi do swych głównych źródeł, czyli Ksiąg Samuela i Królewskich, których treść dowolnie wybiera (pomija), często gruntownie zmienia, modyfikuje i uzupełnia. Księgi te uważa za materiał historyczny, który przepracowuje według uznania, wzbogacając go

9 T. W i 11 i, Die Chronik als Auslegung: Untersuchungen zur literarischen Gestaltung der historischen Überlieferung Israels, FRLANT 106, Vandenhoeck \& Ruprecht, Göttingen 1972, s. 66; R. S m e n d, Die Entstehung des Alten Testaments, TW 1, W. Kohlhammer, Stuttgart 1978, s. 228-229; J. B e c k e r, 1Chronik, NEB 18, Echter Verlag, Würzburg 1986, s. 6.

10 P. A b a di e, 1-2 Chroniques, w: T. Rö me r, J.D. M a c c h i, C. N i h a n (red.), Introduction à l'Ancien Testament, s. 597; I. G a b r i e 1, Friede über Israel. Eine Untersuchung zur Friedenstheologie in Chronik I 10 - II 36, OBS 10, Österreichisches Katholisches Bibelwerk, Klosterneuburg 1990, s. 5. 
o własne komentarze i inne dostępne mu źródła, ${ }^{11}$ tak by dostosować go do przyjętych wcześniej priorytetów ideowo-teologicznych. ${ }^{12}$ Model jego edytorskiej pracy nie przypomina więc aktywności komentatora, który zawsze $\mathrm{z}$ respektem podchodzi do tekstu natchnionego (kanonicznego), nie dokonuje w nim zmian, a jedynie go komentuje i objaśnia. Celem Kronikarza nie była egzegeza, dlatego często po prostu kopiuje oryginalne źródła bez jakichkolwiek objaśnień, choć tego domagałaby się ich treść, niezrozumiała dla lektora epoki Drugiej Świątyni. Ponadto duża część materiału narracyjnego w obu Księgach Kronik nie znajduje wzorca w innych tekstach Biblii Hebrajskiej, a ich aktualna forma literacka oraz styl przekazu daleko odbiega od analogicznych tekstów z Pięcioksięgu czy dzieła deuteronomistycznego. Analizując sposób, w jaki Kronikarz selekcjonuje, modyfikuje i interpretuje swe źródła, należy stwierdzić, że jego dzieło nie jest ideowym czy teologicznym komentarzem do wcześniejszych tradycji, lecz oryginalną i pełnowartościową historiozbawczą wizją faktów i postaci, stworzoną według precyzyjnych kryteriów historiografii uznawanej w epoce powygnaniowej. W ich świetle okres przedwygnaniowej historii Izraela, a szczególnie czas Saula, Dawida i Salomona, nabiera nieco innego wydźwięku aniżeli ten prezentowany w dziele deuteronomistycznym (Joz-2Krl), choć stricte historyczna wiarygodność Ksiąg Kronik w wielu miejscach budzi wiele kontrowersji. ${ }^{13}$

Szukając definicji dla dzieła Kronikarza, niektórzy sugerują, by interpretować je w kategorii pisma teologicznego mającego podkreślić religijny charakter dziejów Izraela relacjonowanych z perspektywy idei przymierza z JHWH. Komentując kolejne partie Kronik, egzegeci optujący za tą koncepcją twierdzą, że jego najważniejszym

${ }^{11}$ O. E i s s fe $1 \mathrm{~d}$ t, The Old Testament, an Introduction, Harper \& Row, New York 1965, s. 540.

12 R. M o s i s, Untersuchungen zur Theologie des chronistischen Geschichtswerkes, FTS 92, Herder, Freiburg 1973, s. 12-13; I. K a 1 i m i, Reshaping of Ancient Israelite History in Chronicles, Eisenbrauns, Winona Lake 2005, s. 36-52,140-158.

13 R. K le i n, 1Chronicles. A Commentary on 1Chronicles, Fortress Press, Minneapolis 2006, s. 23-26. 
przesłaniem jest ukazanie zbawczego, a nie historycznego aspektu relacjonowanych faktów. ${ }^{14}$ Ich zdaniem Kronikarz to wytrawny teolog, który dzieje swego narodu interpretuje w duchu monoteistycznego jahwizmu, akcentując, że najważniejszym czynnikiem kreującym historię Izraela jest zbawcza wola i obecność JHWH. ${ }^{15}$ Trudno zaprzeczyć tym tezom. Istotnie Kronikarz w każdej części swego dzieła podkreśla, że JHWH rozciąga władzę nad całym światem i jego narodami (1Krn 29,11; 2Krn 20,6; 25,7-9), przenika wszystko swym wejrzeniem $(2 \mathrm{Krn} 16,9)$ i nic nie dzieje się bez Jego woli i wiedzy (1Krn 28,9; 29,17; 2Krn 6,30). Tylko On decyduje o biegu historii, posługując się w realizacji swych planów konkretnymi ludami i ich władcami (1Krn 5,26; 2Krn 21,16; 36,17-23). Jednak mimo wyraźnego teologicznego podtekstu Pierwszej i Drugiej Księgi Kronik ich autor nie jest tylko teologiem, który odczytuje dawne i bliskie dzieje Izraela w świetle idei przymierza z JHWH. Jest on również pełnoprawnym historykiem zainteresowanym rzetelną dokumentacją faktów i postaci, choć czyni to według standardów historiograficznych obowiązujących w swej epoce. ${ }^{16}$

W kontekście tych opinii najbardziej adekwatną definicją dziejopisarskiej aktywności Kronikarza jest historiografia judaistyczna. Ten gatunek biblijnej prozy należy rozumieć jako obszerną literacką relację sekwencji przeszłych zdarzeń z dziejów Izraela powstałą na

14 P. A c k roy d, The Theology of the Chronicler, LTQ 8/1973, s. 108; t e n ż e, The Chronicler as Exegete, JSOT 2/1977, s. 2-3; J. C o g g i n s, The First and Second Books of the Chronicles, CBC, Cambridge University Press, Cambridge 1976, s. 5-6.

15 J. P a y n e, 1,2 Chronicles, EBC 4, Zondervan, Grand Rapids 1988, s. 314-315; J. M c K e n z i e, A Theology of the Old Testament, Doubleday, Garden City 1974, s. 27; I. K a 1 i m i, Starożytny historyk izraelski. Studium o Kronikarzu, jego epoce, miejscu działalności i dziele, Nomos, Kraków 2016, s. 48.

16 Jednym z fundamentów starożytnej historiografii było przekonanie o decydującym wpływie woli Boga (bogów) na losy ludów i ich władców, co widać w każdej części Biblii Hebrajskiej, a także w większości znanych pomników starożytnej literatury pozabiblijnej oraz bliskowschodnich artefaktów. J. P r i t c h a r d (red.), Ancient Near Eastern Texts Relating to the Old Testament, Princeton University Press, Princeton 1969, s. 235, 277, 320; E. G a 1 b i a t i, F. S e r a f i n i, Historyczny atlas Biblii, Jedność, Kielce 2006, s. 18-22. 
podstawie analiz i relektury wiarygodnych źródeł oraz w przekonaniu o ich ścisłej zależności od Boga. Historiograf biblijny, w tym przypadku Kronikarz, relacjonując dzieje własnego ludu, nie tylko je opowiada, ale też dogłębnie i wielopłaszczyznowo objaśnia i interpretuje, łącząc ze sobą historyczne fakty i postacie na zasadzie zależności przyczynowo-skutkowej, czyli wskazując ich najważniejsze powody i konsekwencje. By mogła powstać taka historyczna proza, jej autor winien wciąż odwoływać się do konkretnego i precyzyjnego systemu wartości (społecznych, etyczno-religijnych). Ponadto winien stosować kryteria literackie, którym przyświeca jedna centralna idea wiodąca lub kilka węższych, ale uzupełniających się wątków narracyjnych, co pozwala harmonijnie i wiarygodnie ${ }^{17}$ dobierać, oceniać, porządkować i komentować opracowywane źródła i tradycje. Jak większość dziejopisarzy starotestamentowych, Kronikarz interpretuje historię Izraelitów w świetle teologicznej idei ich Bożego wybraństwa i wiecznej relacji przymierza opartego na nieodwołalnych Bożych obietnicach ziemi, licznego potomstwa i błogosławieństwa. Ta teologiczna podbudowa jest stałą i fundamentalną kategorią, która w różnej formie i zakresie leży u podstaw każdej formy biblijnej historiografii, ukazując, że to, co na przestrzeni wieków przydarza się Izraelitom, ma zawsze ścisły związek z Bogiem JHWH i zależy od ich wierności wobec zawartego z Nim przymierza (zasada retrybucji).

17 Mówiąc o stopniu wiarygodności treści komunikowanych przez Kronikarza, należy stwierdzić, że w zdecydowanej części dzieła oferuje informacje „z trzeciej ręki”, to znaczy opiera się na tradycjach utrwalonych w Księgach Samuela i Królewskich, które z kolei bazują na starszych przekazach i tradycjach (ustnych i pisanych). Biorąc jednak pod uwagę, że w wielu miejscach Kronikarz odbiega od historiograficznego nurtu obu Ksiąg Samuela i Królewskich, nie można wykluczyć, że i on proponuje informacje ,z drugiej”, a nawet ,z pierwszej ręki”, czyli odwołuje się do autentycznych źródeł, które nie znalazły odzwierciedlenia w historiografii deuteronomistycznej. Kronikarza dzielą wieki od relacjonowanych prze niego zdarzeń, a on tak dobierał, modyfikował i interpretował dostępne mu źródła, żeby ukazać zupełnie nową perspektywę historii Izraela w stosunku do tej oferowanej przez deuteronomistów czy innych judaistycznych dziejopisarzy. 
O takiej teologicznej i historycznej wartości faktów i postaci opisywanych w obu Księgach Kronik - rozumianej oczywiście w kluczu biblijnej historiografii - przekonane są kręgi odpowiedzialne za redakcję greckiej LXX, dlatego umieściły je bezpośrednio po tzw. Księdze Królów (e biblos basileiōn), na którą składają się Księgi Samuela i Królewskie. W ten sposób dzieło Kronikarza zostało zrównane z poprzedzającymi je w kanonie greckim księgami, których historycznej wartości nigdy nie podważano. Kronikarza potraktowano jako pełnoprawnego historiografa, który w redakcji swego dzieła oparł się na powszechnie uznawanych i poważanych ówcześnie ${ }^{18}$ świadectwach historycznych (1-2Sm; 1-2Krl), a także wielu innych źródłach i tradycjach, które obficie przytacza (1Krn 9,1; 27,24; 29,29; $2 \mathrm{Krn} 9,29 ; 12,15 ; 13,22 ; 16,11 ; 20,34 ; 24,27 ; 25,26 ; 26,22 ; 27,7 ; 28,26$; $32,32 ; 33,18-19 ; 35,25) .{ }^{19} \mathrm{~W}$ procesie systematyzacji i oceny tych źródeł kieruje się własną metodologią odzwierciedlającą modele historiografii helleńskiej, co sprawia, że jego dzieje Izraela, a szczególnie sekcja o ukonstytuowaniu się monarchii, nabiera znacząco innego kolorytu niż dużo starsze wzorce literackie proponowane przez deuteronomistów. Po lekturze Kronik można sądzić, że ich autor miał krytyczne podejście do źródeł, wybierał tylko te, które odpowiadały jego koncepcji zdarzeń, a następnie łączył je w jedną literacką całość, opatrując precyzyjną oceną ideowo-teologiczną. ${ }^{20}$ Jego sposobem

18 Datacja ostatecznej redakcji Kronik jest kwestią złożoną, dlatego prawie każdy z komentatorów przyjmuje własną chronologię. Najbardziej prawdopodobną i najczęściej sugerowaną przez współczesnych egzegetów hipotezą jest okres pierwszych trzech dziesięcioleci IV w. przed Chr.

19 Wymieniane na poszczególnych stronach pierwszej i Drugiej Księgi Kronik źródła i tradycje sprawiają wrażenie konkretnych i autonomicznych tradycji (dokumentów pisanych), które mają własną nazwę i cieszą się powszechnym uznaniem i wiarygodnością. Zdecydowana ich liczba pojawia się w Biblii Hebrajskiej tylko i wyłącznie w dziele Kronikarza, co utrudnia ich historyczną weryfikację. Brak faktograficznej wiarygodności niektórych passusów obu Ksiąg Kronik nie powinien jednak w żadnym razie kwestionować ich literackiej i historiograficznej oryginalności.

20 Zgodnie ze standardami historiografii biblijnej, widocznej w bloku Księga Jozuego-Druga Księga Królewska i literaturze epoki Drugiej Świątyni, Kronikarz 
procedowania była harmonizacja i interpretacja napotykanych w materiale źródłowym trudności i sprzeczności, a nierzadko upraszczanie i pomijanie kontrowersyjnych lub niejasnych fragmentów.

Historiograficzną metodologię Kronikarza widać wyraźnie na przykładzie opisu rządów Saula i Dawida, który stanie się przedmiotem badawczym pozostałej części artykułu. Sposób podejścia do źródeł, kryteria ich doboru, a przede wszystkim ton ich lektury, wyraźnie wskazują na pro-Dawidowe i projudzkie sympatie Kronikarza. To one przesądziły o aktualnym, niestety mało pochlebnym wizerunku pierwszego władcy Izraela. Analiza przyjętych w Pierwszej Księdze Kronik technik narracji oraz zastosowanych metod historiograficznych dowodzi, że jego rekonstrukcja historii Izraela nie jest zwyczajną kalką wcześniejszych źródeł. ${ }^{21}$ Nie jest też ich zręczną kompilacją, a tym bardziej nie jest opowieścią o dziejach Izraela opartą na wystudiowanej i fikcyjnej fabule historycznej. ${ }^{22}$ Kroniki są przykładem profesjonalnego dziejopisarstwa, a ich autor miał doskonały historiograficzny warsztat pisarski i tak nim operował, że na bazie już istniejących źródeł stworzył zupełnie nowe dzieło pod względem szaty literackiej ${ }^{23} \mathrm{i}$ ideowo-teologicznego przesłania. Współczesnym sobie czytelnikom Kronikarz zaoferował treści, które umożliwiały krytyczne spojrzenie na historię Izraela z dwu różnych perspektyw. Z jednej strony zaprosił do retrospekcji historycznej na bazie dobrze znanych w ówczesnych środowiskach Izraela Ksiąg

wkładał własną ocenę opisywanych zdarzeń i postaci w usta głównych bohaterów narracji. Głównym celem tego zabiegu literackiego było zaproszenie współczesnych mu Izraelitów do pogłębionej refleksji nad historiozbawczym sensem ich przeszłości, by w świetle powszechnie uznawanych w Izraelu wartości społeczno-kulturowych i religijnych mogli na nowo kształtować własną teraźniejszość i przyszłość.

21 J. Van Sete r s, Creative Imitation in the Hebrew Bible, SR 29/2000, s. 399-400.

22 R. P fe iffe r, Introduction to the Old Testament, Harper \& Brothers, New York 1957, s. 806.

23 E. B e n Zv i, The Book of Chronicles: Another Look, SR 31/2002, s. 277. 
Samuela i Królewskich, z których bardzo obficie czerpał. ${ }^{24}$ Zaś z drugiej, zaproponował nową i niepowtarzalną rekonstrukcję historiograficzną opartą na kilku ważnych filarach ideowych i teologicznych, m.in.: dynastii Dawida, ${ }^{25}$ Jerozolimie rozumianej jako stolica Izraela,

24 Analizując kolejne sekcje Pierwszej i Drugiej Księgi Kronik, można wnioskować, że ich redaktor nie chciał w żadnym razie stworzyć konkurencyjnego dzieła dla Ksiąg Samuela i Królewskich. Ich renoma w jego epoce była niepodważalna, tak więc nie mógł pozwolić sobie na ich pominięcie, a jedynie na modyfikację i nowe ujęcie zawartych w nich źródeł. Właściwe zrozumienie formy literackiej i merytorycznej treści Pierwszej i Drugiej Księgi Kronik jest możliwe tylko wtedy, gdy ma się ciągle w pamięci wersję zdarzeń oferowaną przez historiografię deuteronomistyczną. Mówiąc o genezie i charakterze obu Ksiąg Kronik, współczesna egzegeza proponuje, m.in., koncepcję tzw. Rewritten Bible „Biblii spisanej (opowiedzianej) na nowo", w myśl której historiografowie okresu Drugiej Świątyni wypracowali ściśle określoną strategię narracyjną polegającą na ponownym spisywaniu tradycji (wydarzeń i postaci) znanych z Biblii Hebrajskiej w świetle kontekstu historycznego i kulturowo-religijnego epoki perskiej i helleńskiej, a więc również obowiązujących wtedy standardów teologicznych i literackich. Ta nowa edycja uznanych i pieczołowicie przekazywanych w religijnych środowiskach Izraela świętych przekazów wiązała się oczywiście z odpowiednimi korektami i elaboracjami oryginalnych źródeł, a niekiedy nawet $\mathrm{z}$ ich gruntownym przepracowaniem formalnym i merytorycznym. W duchu idei Rewritten Bible, prócz dzieła kronikarskiego, interpretowane są obecnie również takie sztandarowe relikty żydowskiej literatury apokryficznej, jak: Ksiega Jubileuszów, 4QReworked Pentateuch, Testamenty Dwunastu Patriarchów, a także dzieła Józefa Flawiusza, Filona czy pisma samarytańskie. Obszerną i wieloaspektową prezentację tej hermeneutycznej idei zawierają, m.in., publikacje: J. Z s e n g e 11 é r (red.), Rewritten Bible after Fifty Years: Texts, Terms, or Techniques? A Last Dialogue with Geza Vermes, JSJ.S 166, Brill, Leiden 2013; M. S e g a 1, Between Bible and Rewritten Bible, w: M. H e n z e (red.), Biblical Interpretation at Qumran, Eerdmans, Grand Rapids 2005, s. 10-28.

25 Dzieje własnego narodu Kronikarz ujmuje w teologiczne ramy biblijnej historii zbawienia, której bieg wyznaczają nade wszystko stopniowo realizujące się Boże obietnice złożone patriarchom. Społeczność Izraela epoki powygnaniowej Kronikarz rozumie jako dziedzica patriarchalnej wspólnoty pokoleniowej, przez którą JHWH - Bóg Izraela, postanowił okazać błogosławieństwo i łaskę wszystkim narodom (Rdz 11,27 - Wj 1,7). To dlatego czytelnik Pierwszej Księgi Kronik wpierw poznaje prehistorię ludzkości (1,1-27), potem prehistorię Izraela (od Abrahama do Jakuba; 1,28-53), a w końcu dzieje dwunastu synów (pokoleń) Jakuba-Izraela (2,1-55). Ten ostatni passus genealogii komunikuje teologiczną wizję zjednoczonego 
instytucji kapłaństwa czy kulcie świątynnym, wokół którego - w jego opinii - winno kształtować się codzienne życie członka narodu wybranego. ${ }^{26}$ Tylko tak dostosowane do aktualnej sytuacji historycznej Księgi Kronik mogły bowiem posłużyć Izraelitom okresu Drugiej Świątyni jako narzędzie do kolejnego obrachunku z przeszłością. I tak dzieje judaistycznej historiografii zatoczyły wyraźny krąg, gdyż pierwszego zbiorowego rozrachunku z przeszłością dokonały przed i w trakcie niewoli babilońskiej środowiska deuteronomistyczne, odpowiedzialne, m.in., za wieloetapową redakcję obu Ksiąg Samuela i Królewskich. Po kilku stuleciach na te same zdarzenia, fakty i postacie powygnaniowa wspólnota Izraela, Judy i Jerozolimy, do których Kronikarz skierował swe dzieło, miała okazję popatrzeć raz jeszcze, ale już z innej perspektywy historiozbawczej.

\section{Saul, syn Kisza, w historiograficznej ocenie Pierwszej Księgi Kronik - panorama tekstów}

W świetle powyższych precyzacji na temat literackiego i ideowo-teologicznego profilu dzieła Kronikarza łatwiej będzie

Izraela, podprowadzając pod dzieje potomków Judy, a szczególnie historię Dawida i jego dynastii przed niewolą babilońską (3,1-16) oraz losy potomków syna Jessego po wygnaniu (3,17-24). W tym kontekście Kronikarz na dalszym etapie genealogii prezentuje społeczną podstawę przyszłej monarchii Judy (pokolenia Judy i Symeona; 4,1-43), następnie pokolenia Transjordanii: Rubena (5,1-10), Gada (5,11-23), Manassesa z Zajordania (5,23-26), a dopiero na końcu grupę sześciu rodów, które tworzyły Królestwo Północne: Issachara (7,1-5), Beniamina (7,6-12), Neftalego (7,13), zachodnią część Manassesa (7,14-19), Efraima (7,20-29) i Asera (7,30-40). W tym zestawieniu pokoleń Kronikarz nie kieruje się chronologicznym porządkiem narodzin synów Jakuba ( $R d z$ 49,1-28; por. Rdz 29,31 - 30,24; 35,16-19), ani tożsamością ich matek (46,8-25) czy porządkiem utrwalonym w analogicznych źródłach, z których prawdopodobnie korzystał (Lb 26,23-51). Pomija, np. Zabulona (Lb 26,26-27) i Dana (26,42-43), i zamienia miejscami pozostałe rody. W Lb 26,25--51 pokolenia figurują bowiem w kolejności: Issachar, Zabulon, Manasses, Efraim, Dan, Aser, Neftali.

26 Centralną część sekcji genealogii $(2,1$ - 9,1) Kronikarz poświęca pokoleniu Lewiego i wywodzącym się od niego rodom kapłańskim $(5,27-6,38)$, a następnie stworzonym przez nie strukturom kultycznym (6,39-66). 
skoncentrować się na zasadniczym przedmiocie badawczym artykułu, czyli sposobie prezentacji pierwszego oficjalnego władcy Izraela - Saula. Pierwszym wnioskiem, jaki nasuwa się po lekturze Pierwszej Księgi Kronik, jest systematyczne i zupełnie niespodziewane w zestawieniu z Pierwszą Księgą Samuela pomijanie syna Kisza w relacjonowaniu procesu narodzin monarchii w Izraelu. Choć ta instytucja cieszy się dużym zainteresowaniem Kronikarza, o czym świadczy obszerny blok tematyczny o rządach Dawida w Hebronie i Jerozolimie (11,1 - 29,30), postać Saula została z tego materiału źródłowego w dużej mierze usunięta. Świadoma marginalizacja wkład syna Kisza w proces ukonstytuowania się społeczno-politycznych i militarnych struktur monarchii w Izraelu staje się jeszcze bardziej ewidentna, gdy weźmie się pod uwagę przestrzeń, jaką ten temat zajmuje w Księgach Samuela będących w tej kwestii podstawowym źródłem informacji dla Kronikarza (1Sm 9,1 - 31,13; 2Sm 1,1 - 4,12; 9,1-13; 16,5-13; 21,1-14). Nie bacząc na rozpiętość i bardzo jasne przesłanie trzech kolejnych cykli tradycji Pierwszej Księgi Samuela, w których syn Kisza jest głównym bohaterem, ${ }^{27}$ Kronikarz zupełnie pomija ich orędzie podkreślające aktywny udział Saula w wojnie z Filistynami i budowaniu pierwszych struktur monarchii w Izraelu, tak aby lektor jego dzieła miał wrażenie, że władza królewska rozpoczyna się dopiero od Dawida $(11,1$ - 29,30). Co więcej, nieliczne informacje o Saulu, jakie Kronikarz postanowił pozostawić w swej autorskiej wizji tego etapu dziejów, zostały tak dobrane i skomentowane, że rzucają na figurę pierwszego władcy Izraela bardzo negatywne światło. Aby ukazać tę dwupoziomową ${ }^{28}$ anty-Saulową relekturę

27 Chodzi o zbiory tradycji: o ustanowieniu monarchii (1Sm 7,2 - 12,25), o rządach Saula (1Sm 13,1 - 15,35) oraz o dojściu Dawida do władzy (1Sm 16,1 - 2Sm 5,5), w których syn Kisza jest postacią pierwszoplanową albo jedną z pierwszoplanowych postaci narracji.

28 Negatywna ocena figury i aktywności Saula jest bez wątpienia elementem zaplanowanej strategii narracyjnej Kronikarza, którą systematycznie i skrupulatnie realizuje na kolejnych etapach księgi. Założeniem tej historiograficznej metodologii jest świadome pomijanie tradycji o Saulu, a zarazem krytyczna i arbitralna ocena jego wielorakich wysiłków i zasług położonych w budowę militarnych 
oryginalnych źródeł Pierwszej Księdze Kronik, na tym etapie analizy zostaną zestawione i pokrótce omówione wszystkie teksty, które pośrednio lub bezpośrednio odnoszą się do Saula. Z tej prezentacji wyłączony zostanie jedynie opis jego śmierci (10,1-14), który z uwagi na swą obszerność i przesłanie ideowo-teologiczne zostanie omówiony w finalnej części artykułu.

Już na wstępie należy zaznaczyć, że wszystkie informacje o Saulu zostały skumulowane w Pierwszej Księdze Kronik. ${ }^{29}$ Jest ich tylko dwanaście $(5,10 ; 8,33 ; 9,39 ; 10,114 ; 11,2 ; 12,12.20 .24 .30 ; 13,3 ; 15,29$; $26,28)$ i, co ważne, we wszystkich przypadkach, poza opisem śmierci króla w 10,1-14, mają formę lapidarnych adnotacji, które w żaden sposób nie wpływają na bieg relacjonowanych w księdze zdarzeń. Już z tego prostego zestawienia jasno wynika, że Saul, w opinii Kronikarza, był bohaterem drugiego planu, który w żaden istotny sposób nie wpisał się w historię własnego narodu. Jego obecność w Pierwszej Księdze Kronik została w całości włączona w przekaz o dojściu Dawida do władzy, w którym funkcjonuje w roli negatywnego paradygmatu (antywzoru) dla syna Jessego.

i społeczno-politycznych podwalin ustroju monarchicznego w Izraelu na przełomie XI i X w. przed Chr.

29 Hebrajski rdzeń š’wl „(wy)proszony”, który tworzy imię pierwszego króla Izraela, pojawia się w Biblii Hebrajskiej w dwu różnych kontekstach znaczeniowych. W tradycjach prorockich (Iz 5,24;14,9.11.15; 28,15.18; 38,10.18; 57,9; Ez 32,21.27 Oz 13,14; Jon 2,3), mądrościowych (Hi 7,9; 17,13; 21,13; 24,19; Prz 5,5; 7,27; 9,18; 15,11; 27,20; 30,16) i psalmach (Ps 18,6; 30,4; 49,15-16; 55,16; 89,49; 116,3; 139,8; 141,7) zwykle określa Szeol, czyli przestrzeń, do której po śmierci udają się zmarli. W kilku psalmach ten rdzeń definiuje imię Saula (Ps 18,1; 57,1; 59,1), zaś w Iz 10,29 przynależną do syna Kisza miejscowość - Gibea. W deuteronomistycznej historiografii rdzeń $\check{s}$ ’wl występuje prawie zawsze w odniesieniu do Saula, syna Kisza, pochodzącego z rodu Beniamina. W dziele Kronikarza leksem ten pojawia się 27 razy, tylko w 1Krn 1,48.49; 4,24; 5,10; 8,33; 9,39; 10,2-8.12-13; 11,2; 12,1.2.10.24.30; 13,3; 15,29. Z wyjątkiem tekstu 1,48-49, gdzie określa jednego z potomków Ezawa - Saula, następcę Samli z Masreki, króla z Rechobot Nadrzecznego, a także 4,24, w którym mówi się o Saulu - jednym z pięciu synów patriarchy Symeona, Pierwsza Księga Kronik używa terminu $s^{a} \bar{a}$ ûl wyłącznie w odniesieniu do Saula, syna Kisza. 
Pierwsze trzy noty o Saulu w Pierwszej Księdze Kronik (5,10; 8,33 ; 9,39) mają wydźwięk chronologiczny i biograficzny, wpisując się w pełni w genealogiczny styl pierwszej części księgi, którą prawie w całości wypełniają rodowody hebrajskich klanów i pokoleń od ich najgłębszych korzeni aż po rządy Dawida $(1,1-9,44) .{ }^{30}$ By ukazać długowieczność Izraela i podkreślić jego społeczno-kulturową i religijną przynależność do wielkiej rodziny cywilizacji starożytnego świata, autor Pierwszej Księgi Kronik wyprowadza genezę ludu wybranego (wywodzącego się od dwunastu synów Jakuba, por. 2,1 $8,28)$ już od pierwszego człowieka - Adama, a potem kolejno: od Abrama (Abrahama - „ojca mnóstwa”, 1,1-26) i jego potomnych, czyli Izaaka i Jakuba (1,28-53). Rekonstruując drzewo genealogiczne Jakuba (Izraela), Kronikarz od początku akcentuje pozycję pokolenia Judy, rodu Jessego i Dawida (2,1-17.20-41.50b-55; 3,1-24) oraz spokrewnionego z nim klanu Kaleba (2,9.18-19.42-50a). W ten sposób proponowany przez Kronikarza spis dwunastu rodów Izraela na czele sytuuje pokolenie Judy, a nie Rubena, a nadto, już na etapie tego patriarchy i jego potomnych wprowadza motyw królewskiej dynastii Dawida trwającej do przesiedlenia babilońskiego (3,1-16),

30 Teologiczny profil pierwszej części Pierwszej Księgi Kronik opiera się na trzech teologicznych filarach. Pierwszym z nich jest idea Izraela jako jednolitego społecznie, religijnie i kulturowo narodu stworzonego przez Boga JHWH i wybranego z całej rodziny ludzkiej. Naród ten został zbudowany na patriarchalnych strukturach klanu Jakuba, ale też na Bożych obietnicach obejmujących swym zasięgiem wszystkie narody świata (Rdz 12,1-3). Drugim filarem kronikarskiej wizji dziejów Izraela jest przymierze Dawidowe, na bazie którego Bóg Izraela wybrał i umiłował syna Jessego, a następnie zagwarantował jego potomnym stałe prawo do tronu królewskiego (dynastia) i trwałą pomyślność (2Sm 7,1-16; 23,1-7; $1 \mathrm{Krl} 2,4 ; 6,12 ; 11,34.36$ ). Pro-Dawidowe nachylenie Kronikarza widać wyraźnie w aktualnej strukturze jego dzieła, poświęconego prawie w całości dziejom Dawida (1Krn 3,1 - 4,23; 11,1 - 29,30), Salomona (2Krn 1,1 - 9,31) i pozostałych członków królewskiej dynastii sprawujących władzę w Judzie aż do niewoli babilońskiej (2Krn 10,1-36,23). Trzecim teologicznym filarem obu Ksiąg Kronik jest czołowa rola Jerozolimy w strukturze monarchii Dawida, w której to miasto funkcjonuje jako społeczno-religijne centrum dzięki wzniesionej w nim świątyni zapewniającej stałą obecność JHWH (9,2-34; por. 11,4-9; 13,1-14; 15,1 - 17,21; 22,1 - 29,25). 
a nawet okresu powygnaniowego (3,17-24). Ten fakt jest niezwykle istotny z perspektywy badanego wątku Saula, bo choć Kronikarz w genealogii synów Jakuba mówi aż dwukrotnie o Beniaminie, od którego pochodzi syn Kisza, to ani raz nie wspomina o jego królewskiej władzy $(7,8-12 ; 8,140)$. Takie zestawienie tradycji, które radykalnie odbiega od struktury i treści materiału źródłowego, z którego korzystał Kronikarz (1Sm 9,1 - 2Sm 9,13), zdradza jego poglądy. W jego opinii, instytucja króla w Izraelu została trwale zakorzeniona w pokoleniu Judy ${ }^{31}$ i od początku była związana z rodem Dawida. ${ }^{32}$ Dlatego już na wstępie spisu potomków Jakuba (Izraela) pomija porządek chronologiczny (kolejność urodzin synów Jakuba) typowy dla innych genealogii biblijnych, umieszczając na pierwszym miejscu pokolenie Judy (2,1-55), a zaraz potem Dawida i jego synów, którzy tworzyli dynastię królewską do upadku monarchii (3,1-16). Autorytet tej dynastii, zdaniem Kronikarza, był tak wielki, że postanowił wyliczyć potomków Dawida żyjących w Jerozolimie i poza jej granicami również po niewoli babilońskiej, mimo że nie piastowali już władzy królewskiej (3,17-24).

W kontekście tak mocno akcentowanego wątku rodu Dawida sporadyczne informacje o Saulu i jego krewnych (pokolenie Beniamina, klan Kisza) są w tej sekcji księgi tak niepozorne, że z pewnością nie przyciągnęłyby uwagi lektora, gdyby nie pamięć o obszernym i miejscami niezwykle pozytywnym dla syna Kisza materiale źródłowym z Ksiąg Samuela. Tylko bowiem na zasadzie ciągłego odwoływania się do tego materiału czytelnik Biblii Hebrajskiej może w dziele

31 Można się tu dopatrywać projudzkich sympatii Kronikarza, które łatwo zrozumieć, gdy weźmie się pod uwagę czas i miejsce jego aktywności historiograficznej. W tej kwestii podziela on przekonanie wywodzących się z Judy środowisk deuteronomistycznych, które we własnej historii monarchii na wszystkich płaszczyznach oceny (poszczególni władcy, dynastie królewskie, społeczności narodowe) potępiają Królestwo Północne i jego królów, a pochlebnie wypowiadają się na temat monarchów i społeczności Królestwa Południowego (Juda).

32 E. Z e n g e r, Introduzione all'Antico Testamento, Editrice Queriniana, Brescia 2005, s. 395-396. 
Kronikarza zauważyć Saula i od razu postawić pytanie o powody jego marginalizacji. ${ }^{33}$

Pierwszy raz Kronikarz wymienia imię Saula w genealogii pierworodnego syna Jakuba - Rubena (5,1-10), która, z uwagi na wskazane wyżej względy ideowo-teologiczne, figuruje w księdze dopiero po spisie rodu Judy $(2,1-4,23)$ i sprzymierzonego z nim Symeona (4,24-43; por. Sdz 1,3). Wzmianka ta ma znaczenie marginalne, gdyż w formie adnotacji chronologicznej pomaga Kronikarzowi w precyzacji okresu, w którym Rubenici toczyli walki z Hagrytami. Z wiersza 5,10 można się dowiedzieć, że te działania zbrojne miały miejsce bîmê šă $\hat{u} l$ - „za dni Saula” i pozwoliły Rubenitom zająć majątek nomadycznych Hagrytów i trwale osiedlić się we wschodnim Gileadzie. Kronikarz podaje w 5,10 kilka detali na temat małoistotnego sukcesu militarnego Rubenitów, ale ani jednym słowem nie wspomina o królewskiej władzy Saula, przytaczając jedynie jego imię, by ułatwić czasową lokalizację tego faktu. Biorąc pod uwagę treść źródeł, z których korzystał, oraz tak mocne podkreślenie królewskiej władzy Dawida w najbliższym kontekście wiersza 5,10 (por. 3,1-24), należy sądzić, że taka forma tej informacji nie jest przypadkowa, ale wpisuje się w jego stałą strategię narracyjną dotyczącą syna Kisza.

Nieco więcej szczegółów na temat Saula i jego rodu oferują dwie bliźniacze genealogie $(8,29-40 ; 9,35-44),{ }^{34}$ ale i w nich na próżno

33 Ewidentnym i reprezentatywnym przykładem marginalizacji Saula w Pierwszej Księdze Kronik jest sposób narracji przymierza JHWH z Dawidem w 1Krn 17,13, w którym Kronikarz nie tylko powiela informację o odrzuceniu pierwszego władcy Izraela przez JHWH, ale też świadomie wymazuje jego imię ze źródłowej wersji zdarzeń (por. 2Sm 7,15), nazywając go „tym, który był przed tobą [Dawidem]”.

34 Obecność dwu prawie jednobrzmiących genealogii rodu Saula (8,29-38 i 9,35-44) w tej sekcji księgi można uważać za owoc złożonego procesu edycji Pierwszej Księgi Kronik. W kluczu diachronii to tekst 9,35-44 jest oryginalny, a w procesie redakcji został wraz z wierszem 9,34 zdublowany i wkomponowany raz jeszcze w spis potomków Beniamina (8,1-27), który pierwotnie zamykał pierwszą część księgi (por. 9,1). G.N. K n o p p e r s, 1Chronicles 1-29. A New Translation with Introduction and Commentary, AB 12A, Doubleday, New York 2004, s. 519; R. B r a u n, 1Chronicles, WBC 14, Word Books, Waco 1986, s. 127.142; J. T h o m p s o n, 1,2 Chronicles, NAC 9, Broadman \& Holman Publishers, Nashville 1994, 
szukać adnotacji o tak istotnych wydarzeniach, jak: Boże powołanie Saula na króla (1Sm 9,15-16), obdarzenie go charyzmatem ducha JHWH (1Sm 10,10; 16,14), czy akceptacja jego urzędu wodza (nāgîd) i króla (melek) przez proroka Samuela oraz starszych ludu w formie publicznej aklamacji i rytu namaszczenia (1Sm 9,1 - 10,16; 10,17-27; $11,1-15 ; 12,1-25)$. W przeciwieństwie do analogicznych tradycji o Dawidzie (3,1-24), w obu tych tekstach, bazujących na jednym źródle, w żaden sposób nie akcentuje się osoby Saula. W każdym passusie jest on wspomniany tylko raz $(8,33 ; 9,39$; por. $3,1.9)$, jak gdyby niczym nie różnił się od pozostałych członków swego rodu i w żaden sposób nie zapisał się w historii Izraela. Jedynym, może nawet niezamierzonym przez Kronikarza, zabiegiem narracyjnym ${ }^{35}$ akcentującym pozycję Saula jest typ przekazu. Całość rodu jest wpisana w schemat genealogii horyzontalnej (por. 9,35-38.39b-44), a tylko Ner i Kisz, czyli dziadek i ojciec Saula, figurują w sekwencji typowej dla kapłańskiej genealogii wertykalnej: wenēr hôlîd 'et-qî̌s weqî̌s hôlîd 'et-šā' ûl wešă' ûl hôlìd 'et-jehônātān - ,i Ner zrodził Kisza, i Kisz zrodził Saula, i Saul zrodził Jonatana, Malkiszuę...” (8,33a; 9,39a). W zestawieniu z pro-Dawidowym układem genealogii 2,1-9,1 (por. centralną pozycję sekcji 3,1-4,43 o szerokiej koalicji Judy i Symeona, czyli bazie Królestwa Południowego i dynastii Dawidowej) ten szczegół jest jednak prawie niezauważalny, tak że Saul w pierwszej części księgi $(1,1-9,44)$ pozostaje bohaterem drugiego formatu, mimo dużej uwagi, jaką Kronikarz poświęca pokoleniu Beniamina (7,6-12; 8,1-28) i gibeonickiemu klanowi Jejela, od którego wywodził się syn Kisza $(8,29-40 ; 9,35-44)$.

s. 107. W aktualnej strukturze Pierwszej Księgi Kronik druga genealogia rodu Saula (9,35-44) funkcjonuje jako zamierzone i rozszerzone powtórzenie 8,29-38 mające odpowiednio wprowadzić czytelnika w opis śmierci Saula, która kończy definitywnie wpływ jego rodu na sytuację społeczno-polityczną w Izraelu i daje możliwość przejęcia władzy przez Dawida i jego sojuszników.

35 Kronikarz miał w tym względzie dość bogate źródła, np. 1Sm 9,1-2; 14,49-51; 2Sm 9,12. Realizując jednak swą strategię narracyjną, polegającą na deprecjacji i marginalizacji Saula, całkowicie je pominął. 
Druga grupa informacji o Saulu w Pierwszej Księdze Kronik dotyczy dojścia Dawida do władzy w Judzie i Izraelu. Również te noty mają formę lakoniczną i wymowę wyłącznie faktograficzną, która ma ukazać historyczny kontekst opisywanych zdarzeń i politycznie uzasadnić przejęcie rządów przez syna Jessego. W sugerowanej rekonstrukcji faktów Kronikarz konsekwentnie pomija rolę, jaką odegrał Saul w budowaniu monarchicznych struktur w Izraelu, o czym tak szeroko rozpisuje się deuteronomistyczny redaktor Pierwszej Księgi Samuela (por. 9,1-31,13).

Tę sekwencję tekstów inicjuje 1Krn 11,1-3, przypominając na bazie źródła 2Sm 5,1-3 okoliczności, w jakich przedstawiciele wszystkich izraelskich rodów zadeklarowały społeczno-polityczną i militarną jedność z Dawidem w Hebronie i zaproponowały mu królewską władzę nad całym Izraelem. Perykopa 11,1-3 w strukturze Pierwszej Księgi Kronik otwiera sekcję poświęconą rządom Dawida (11,1 29,30) i pełni rolę tekstu autoryzującego jego dojście do władzy w miejsce Saula. Kompilując materiał źródłowy z 2Sm 5,1-3 i 1Sm 16,1-13 (por. 1Krn 11,3) Kronikarz usiłuje podkreślić legalność rządów Dawida. Zgodnie z biblijnymi standardami dozwolonego przejęcia władzy w Izraelu, w 11,1-3 mówi więc o obecności i woli „wszystkich Izraelitów” (kāl-jiśrā'ell) i ,starszych ludu” (kol-ziqnê) w Hebronie, Bożej autoryzacji władzy Dawida (11,2b), a także o zawartym oficjalnie i publicznie przymierzu potwierdzonym rytem namaszczenia na króla (11,3a). By usunąć wszelkie wątpliwości co do Bożego wybraństwa i sposobu przejęcia władzy przez Dawida, które mogły się nasuwać na podstawie lektury niektórych źródeł (1Sm 16,1-2Sm 5,5; 2Sm 9,1-13; 16,5-14; 21,1-14), Kronikarz w 11,3 poszerza tradycję 2Sm 5,1-3, dodając, że namaszczenie syna Jessego dokonało się zgodnie z wolą JHWH przekazaną przez proroka Samuela. W ten sposób opis przejęcia władzy przez Dawida staje się modelowym biblijnym zapisem, w którym nie brak żadnego z istotnych elementów znanych $\mathrm{z}$ analogicznych tradycji o wyborze króla. Co istotne, żaden z biblijnych tekstów o dojściu Saula do królewskiego tronu w Izraelu (1Sm 9,1 -12,25) nie jest tak wzorcowo udokumentowany jak tekst 1Krn 11,1-3. 
Aby potwierdzić kluczową tezę swej pro-Dawidowej relektury ustanowienia monarchii w Izraelu, Kronikarz od razu deprecjonuje militarną aktywność Saula. Przywołując cytowaną w źródle 2Sm 5,2a opinię Izraelitów, już w otwarciu sekcji o rządach Dawida $(11,1$ - 29,30) akcentuje społeczno-polityczną słabość Saula przez zestawienie jej z militarnymi sukcesami Dawida potwierdzanymi przez samych Izraelitów. Przypomina też o Bożym wybraństwie syna Jessego, które stało się powodem ostatecznego odrzucenia urzędującego monarchy $(10,14 b)$. Wiersze 10,14 b i 11,2 to jedyne miejsca w Pierwszej Księdze Kronik, które mówią wprost o tym, że Saul był królem Izraela, ale czynią to w kontekście jej pozbawienia: najpierw przez JHWH, a potem przez Izraelitów. Umieszczenie perykopy 11,1-3 bezpośrednio po opisie śmierci Saula (10,1-14), wzmocnione dodatkowo jej tendencyjną interpretacją w $10.14 \mathrm{~b}$, nie pozostawia lektorowi księgi żadnych wątpliwości: Saul nie sprostał misji nałożonej mu przez JHWH (1Sm 9,15-16). Z tego względu został przez Niego odrzucony, ${ }^{36}$ tak że jeszcze za jego rządów w Izraelu rolę społeczno-militarnego wodza i pasterza pełnił Dawid $(11,2) .{ }^{37}$ Tylko w tym kluczu interpretacji można zrozumieć, dlaczego zaraz po śmierci Saula wszyscy Izraelici zaproponowali Dawidowi królewską godność i rządy w kraju. Podsumowując ideową i teologiczną wymowę wersu 11,2, należy stwierdzić, że jego treść jest wierną kalką 2Sm 5,2. Jednak na tle komentarzy Kronikarza umieszczonych w najbliższym kontekście (por. 10,14; 11,3b) nabiera on zdecydowanie bardziej krytycznej wobec Saula wymowy aniżeli jego źródło.

Kolejne adnotacje o Saulu - jego imię pojawia się aż czterokrotnie w 12,1.2.20.24 - są częścią kronikarskiego opisu dojścia Dawida do władzy $(11,4-12,41)$. W strukturze księgi ta sekcja niejako potwierdza zasadność pochlebnej opinii Izraelitów na temat militarnych działań syna Jessego za rządów Saula wyrażonej w 11,2 (por. 2Sm 5,2;

36 H. D o c k e r y, Holman Concise Bible Commentary, Broadman \& Holman Publishers, Nashville 1998, s. 157; J. W a 1 v o o r d, R. Z u c k, The Bible Knowledge Commentary, Victor Books, New York 1983, s. 603.

37 J. T h o m p s o n, 1,2 Chronicles, s. 116. 
1Krn 12,24), które - ich zdaniem - dawały mu prawo do objęcia tronu. Zbiór tekstów 11,4-12,41 ma niejednakową wartość historyczną. Komunikowane w niej informacje opierają się na 1Sm 16,1 - 2Sm 5,10; 2Sm 21,15-22; 23,8-39 oraz innych źródłach, które nie znalazły odbicia w deuteronomistycznej historiografii. Do tych źródeł należy, na przykład, lista zwolenników Dawida wywodzących się z pokoleń: Beniamina (12,1-8.17-19), Gada (12,9-16), Judy (12,17-19) i Manassesa (12,20-22), którzy - w opinii Kronikarza - udzielili mu w Siklag poparcia w trwającej już od pewnego czasu konfrontacji z Saulem $(12,23)$. Zapisane w tych czterech perykopach imiona izraelskich wojowników mają prawdopodobnie wartość historyczną (por. analogiczny spis w 2Sm 23,8-39), ale ich aktualne przesłanie jest mało wiarygodne i odzwierciedla pro-Dawidowy podtekst Pierwszej Księgi Kronik. ${ }^{38}$ Kontrowersje wywołuje szczególnie informacja o polityczno-militarnym poparciu Dawida przez aż 23 członków rodu Beniamina (12,1-8.17-19), która nie znajduje potwierdzenia w obu Księgach Samuela. ${ }^{39}$ Trudno bowiem przyjąć, że czołowi i waleczni mężowie z rodu Beniamina, a wśród nich nawet krewni i rodacy Saula z jego rodzimego Gibea i zaprzyjaźnionego Gibeonu, już za jego życia przeszli na stronę syna Jessego. Tekst 12,1-7 mówiący o opuszczeniu Saula przez znaczną liczbę sojuszników należałoby raczej odczytać w kluczu ideowej propagandy Kronikarza, który w formie midraszu ${ }^{40}$ postanowił wyjaśnić okoliczności, w jakich

38 Tekst źródłowy 1Sm 21,1 - 2Sm 1,27, który dokładnie opisuje ucieczkę Dawida z dworu Saula, jego współpracę z Akiszem i Filistynami oraz osiedlenie się w Siklag w nagrodę za służbę u filistyńskiego króla (1Sm 27,5-6) - co w swej relacji skrupulatnie przemilcza Kronikarz - o samych sojusznikach Dawida mówi bardzo oględnie, ograniczając ich liczbę do kilkuset (400 lub 600) bezimiennych członków jego rodu oraz uciśnionych lub wyjętych spod prawa i obciążonych długami uciekinierów (1Sm 22,1-2; 27,2).

39 Teksty 2Sm 3,1.6 - 4,12; 9,1-13; 16,5-14, 21,1-14 ukazują, że Beniaminici za rządów Saula i po jego śmierci nie byli sprzymierzeńcami Dawida, lecz usiłowali zachować swe wpływy i uprzywilejowaną pozycję w mocno podzielonej społeczności rywalizujących ze sobą hebrajskich klanów. R. B r a u n, 1Chronicles, s. 165.

40 E. C u rti s, A. M a d s e n, A Critical and Exegetical Commentary on the Books of Chronicles, T\&T Clark, Edinburgh 1994, s. 194-195. 
Dawid stał się dowódcą najdzielniejszych wojowników ${ }^{41}$ i pierwszym powszechnie uznawanym w Izraelu królem: wybranym przez JHWH i zaakceptowanym przez cały lud (10,14; 11,1-3), czyli nawet zwolenników jego politycznego konkurenta. W kontekście 12,1-2 (por. 11,2) Saul jawi się jako przegrany i nieudolny wódz, którego sukcesywnie opuszczają wartościowi i znający wojenne rzemiosło żołnierze, stając się podstawą doborowych oddziałów rywala, m.in. grupy „trzydziestu” (12,19; por. 2Sm 23,13.24-38). W opinii Kronikarza, ta polityczno-militarna dezercja była zjawiskiem powszechnym już za rządów Saula, co wyraża, np. w 12,30, informując, że szeregi beniaminickich krewnych i współpracowników króla opuściło aż trzy tysiące mężów.

W kontekście tych mało wiarygodnych historycznie informacji, które odzwierciedlają założenia pro-Dawidowej ideologii Kronikarza, występują jeszcze dwie adnotacje o Saulu (12,20b.24). Obie odnoszą się do ostatniego etapu dojścia Dawida do władzy, które przebiegało w atmosferze konfliktu z Saulem i na tle wojny Izraelitów z Filistynami (por. 1Sm 16,1 -31,13). Pierwsza z nich $(12,20)$ jest interpolacją Kronikarza opartą po części na bazie opracowywanego przez niego źródła (por. 12,21-22), a po części na parafrazie kłopotliwego dla Dawida materiału źródłowego mówiącego o jego bliskiej współpracy z filistyńskim królem Akiszem (1Sm 27,2-6; 28,1-2). Kronikarz wkłada wiele wysiłku, by zamaskować fakt służby Dawida u Filistynów. W tym celu, w 12,20a wpierw powiela pierwszą część źródła 12,21-22 mówiącą o przejściu na stronę Dawida dzielnych wodzów i tysięcy doborowych żołnierzy z pokolenia Manassesa, a następnie podkreśla absencję syna Jessego w decydującej walce Akisza z Saulem (12,20b). Ten ważny z ideowego i politycznego punktu widzenia szczegół mogący negatywnie wpłynąć na legitymizację

${ }^{41}$ Ilustracją tego gatunku historiograficznej prozy może być np. treść wiersza 12,23, który wielkość i militarną operatywność obozu Dawida w konflikcie z Saulem wyraża za pomocą semickiej formuły stopnia najwyższego: mahăneh gādôl kemahănēh ’ělōhîm - „obóz tak duży jak obóz Boży”. 
władzy Dawida w Izraelu ${ }^{42}$ Kronikarz ukazuje z dużą ostrożnością, przytaczając kulisy przedbitewnych pertraktacji Akisza z jego wodzami, których finałem było oddalenie syna Jessego z najbliższego otoczenia króla na czas walki z Saulem. Celem Pierwszej Księgi Kronik, podobnie jak zamierzeniem redaktora cyklu 1Sm 16,1-2Sm 5,5, było odsunięcie od Dawida jakiejkolwiek odpowiedzialności za tragiczną śmierć Saula, jego synów i wielu Izraelitów (1Sm 31,1 - 2Sm 1,27). Dlatego teksty te dokładnie cytują opinię Filistynów, którzy w Saulu widzą zwierzchnika Dawida ('âdôn - „pan”) i obawiają się, że syn Jessego w każdej chwili może zdradzić Akisza, by za własną dezercję wynagrodzić władcy Izraela głowami filistyńskiego króla i jego dowódców. Ta opinia miała w Izraelu ostatecznie usunąć wszelkie wątpliwości i utwierdzić przekonanie o niezachwianej lojalności Dawida wobec swego narodu i władcy (1Sm 24,1-23; 26,1 - 2Sm 1,27).

Ostatnia aluzja do Saula w sekcji 11,1-12,41 pojawia się w wierszu rozpoczynjącym jej finalny segment $(12,24)$. Wers ten przywołuje raz jeszcze fakt przybycia Izraelitów do Hebronu w celu obwołania Dawida królem (11,1-3.39) i inicjuje opis militarnego wsparcia dla niego ze strony wszystkich pokoleń. ${ }^{43}$ W 12,24 Kronikarz nawiązuje do początku sekcji, czyli perykopy o przymierzu całego Izraela z Dawidem $(11,1-3)$ i swej autorskiej interpretacji przyczyn śmierci Saula $(10,14)$. W wyniku tych zabiegów redakcyjnych opis przejęcia przez Dawida królewskiej władzy w Hebronie $(11,1-12,41)$ w swych wiodących fragmentach powtarza jak refren, że Saul stracił godność i misję króla z woli JHWH, a cały naród, posłuszny Bogu, jednomyślnie uczynił swym władcą syna Jessego. Wyłaniający się z 11,1 - 12,41 obraz Saula, w kontekście wierszy 10,13-14 staje się

42 W tym miejscu Kronikarz bezpośrednio odwołuje się też do pro-Dawidowego źródła z 1Sm 29,4.

43 Warto podkreślić, że 1Krn 12,24-38 zawiera najszerszy starotestamentowy spis hebrajskich pokoleń (13, a nawet 14 samodzielnych klanów), uporządkowany w kluczu geograficznym: od rodów południowych do północnych wraz z Transjordanią. Kronikarska wizja pokoleniowej struktury Izraela na tym etapie narracji ma ukazać jednomyślne wsparcie społeczno-polityczne i militarne dla Dawida; R. B r a u n, 1Chronicles, s. 169-170. 
bardzo negatywny. Kronikarz ukazuje w nim nieposłusznego Bogu wybrańca i nieudolnego wodza, który nie zdołał zrealizować nałożonej mu misji i nigdy nie zyskał powszechnej akceptacji i poparcia u Izraelitów. Ta krytyczna ocena społeczno-politycznej i militarnej aktywności Saula służy w Pierwszej Księdze Kronik za platformę, po której na scenę wydarzeń zostaje wprowadzony Dawid. Od początku narracji jest ukazywany jako Boży wybraniec, cieszący się aprobatą ze strony wszystkich hebrajskich rodów oraz ich świeckich i religijnych przywódców.

Niepochlebną prezentację Saula Kronikarz uzupełnia jeszcze trzema adnotacjami, które dotyczą sfery pobożności i kultu. Motyw ten w strategii narracyjnej Kronikarza nie jest wcale przypadkowy. Zarówno w epoce rodzącej się monarchii, jak i powygnaniowym okresie Drugiej Świątyni, bliska więź króla (lidera) z Bogiem JHWH, wpisana $\mathrm{w}$ teologię przymierza i poparta konkretnymi manifestacjami kultycznymi, była powszechnie uważana za nieodzowny warunek do uzyskania Jego wsparcia i błogosławieństwa, tak potrzebnych do codziennej egzystencji narodu wybranego. Dlatego deuteronomistyczna historiografia i opierający się na niej Kronikarz wielokrotnie akcentują religijno-moralny aspekt życia Saula i Dawida, uzależniając genezę ich misji, jej przebieg, a w końcu pomyślny czy też dramatyczny finał bezpośrednio od woli JHWH (1Sm 9,15-16; 13,8-15; $15,1-35 ; 16,1-14 ; 28,6-19 ; 2 \mathrm{Sm} 2,1 ; 5,17-25 ; 6,1$ - 7,29; 11,27b - 12,25; 17,14; 24,1-25; 1Krn 10,14; 11,2.9; 12,23). Według Pierwszej i Drugiej Księgi Samuela, istotnym rysem pobożności królewskiej pierwszych dwu władców Izraela były: bogaty rytuał ofiarniczy (1Sm 10,8; 11,15; $13,8-15 ; 14,35 ; 15,15 ; 20,7.29 ; 2 \mathrm{Sm} 6,13 ; 24,25)$, praktyka konsultacji JHWH (1Sm 14,37; 23,2.4.9-12; 28,6.7-25; 30,7-8; 2Sm 2,1; 5,19.23-24) i kult związany z sanktuarium (świątynią) JHWH (1Sm 10,3.10; 15,12; 28,3; 2Sm 6,1-23-7,29). W tej materii deuteronomiści wydają dość ambiwalentną ocenę Saulowi, a bardzo pochlebną Dawidowi. Saul jest ukazany z jednej strony jako wybraniec Boga, który realizuje Jego wolę, składa Mu ofiary, szuka Jego rady w rytach konsultacji i odwiedza miejsca kultu. A z drugiej, pokazują go jako władcę, który lekceważy wolę JHWH (nakaz heremu) i autorytet proroka, 
występuje przeciw miejscu kultu i kapłanom w Nob (1Sm 21,6-21), uzurpuje sobie prawo do składania ofiar zarezerwowane prorokowi i nie potrafi skutecznie wejść w bezpośredni kontakt z Bogiem (ryt konsultacji). Na tym samym tle wzorcowo wypada Dawid, który na każdej ze wskazanych wyżej płaszczyzn odnosi sukcesy: jego ofiary owocują łaskawością i przebaczeniem Bożym, ryty konsultacji zawsze spotykają się z odpowiedzią i wsparciem JHWH, a inicjatywa kultu Arki Przymierza i budowy świątyni przynosi owoce w postaci wiecznego przymierza z Bogiem.

Bazując na różnych źródłach, Kronikarz zaznacza z kolei silny rozdźwięk między tymi władcami, czyniąc z Dawida wzór królewskiej pobożności, ${ }^{44}$ zaś z Saula przykład monarchy, który lekceważy Boga i Jego wolę, nie docenia wartości kultu i nie szanuje autorytetu religijnych liderów (proroka i kapłanów). W tę koncepcję wpisują się dwie adnotacje o Arce Przymierza i Saulu w 1Krn 13,3 i 15,29, które są częścią niezwykle rozbudowanej (13,1-14; 15,1 -16,43) i przychylnej Dawidowi reinterpretacji źródła 2Sm 6,1-23. W tej złożonej z kilku źródeł narracji, w której Kronikarz relacjonuje dwuetapowe i pełne kultycznego splendoru sprowadzenie Arki Przymierza z Kiriat-Jearim do Jerozolimy, Saul znów pojawia się zupełnie przypadkowo w obrębie późnych redakcyjnych glos - i zawsze w niekorzystnym świetle. W kontekście opisu Dawidowej inicjatywy sprowadzenia Arki do Jerozolimy, która pojawia się zaraz po inauguracji jego rządów, a nadto jest konsultowana z Bogiem, wszystkimi Izraelitami oraz ich lokalną władzą, kapłanami i lewitami (13,1-3), Kronikarz

44 O takiej ocenie przesądza tematyczny wątek Jerozolimy, jej świątyni oraz kultu Arki Przymierza, które pozostają w centrum całego dzieła. W świetle teologii Kronikarza, religijne inicjatywy Dawida zrealizowane przez Salomona spowodowały, że Jerozolima pozostała jedyną stolicą „Królestwa JHWH” i miejscem „tronu JHWH”. Świątynia jest bowiem w księdze bêt zābah „,domem ofiar” (2Krn 7,12) i miejscem, w którym na wieki przebywa imię JHWH, gdyż „Jego oczy i serce” są na nie zwrócone przez wszystkie dni (2Krn 7,16). Bóg Izraela jest obecny w mieście, bo jest ono ,domem odpoczynku dla Arki Przymierza JHWH, podnóżkiem Jego stóp" (1Krn 28,2; 2 Krn 6,41); M. S e 1 m a n, Jerusalem in Chronicles, w: R. H e s s, G. W e n h a m (red.), Zion City of Our God, Eerdmans, Grand Rapids 1999, s. 48-52. 
ustami króla precyzuje cel tego przedsięwzięcia. Jest nim troska o Arkę Boga, której nie było w okresie rządów Saula. Ta nieprzychylna dla Saula ocena jest opinią Kronikarza, która nie znajduje żadnego potwierdzenia w Pierwszej Księdze Samuela. Co prawda, obszerne źródła o Saulu $(9,1$ - 31,13) nie mówią o kulcie arki JHWH w taki sposób, jak teksty o Dawidzie (2Sm 6,1-7,29), co zresztą jest $\mathrm{w}$ pełni zrozumiałe, gdy weźmie się pod uwagę fakt jej pobytu w filistyńskim Pentapolis i Kiriat-Jearim (1Sm 4,1-7,1) oraz krwawej wojny trwającej aż do śmierci syna Kisza (1Sm 31,1-13). Jednakże wiersz 1Sm 14,18 nie tylko wprost informuje o obecności 'ărôn hà ělōhîm w tym czasie pośród Izraelitów, ale też mówi o rewerencji, z jaką król odnosił się do tego przedmiotu kultu. Dowodem na to jest obecność królewskiego kapłana Achiasza, który stale opiekował się Arką podczas militarnej aktywności monarchy, a także wyraźnie wyrażona wola Saula, by za jej pośrednictwem dokonać rytu konsultacji JHWH. ${ }^{45}$ Treść 1Sm 14,18 każe opinię Kronikarza z 13,3 odczytać w kategorii dość arbitralnego osądu, który koreluje z jego negatywnym nastawieniem do Saula manifestowanym w całej księdze i mającym uzasadnić marginalizację tej postaci.

W analogicznym kluczu należy rozumieć pośrednią aluzję do Saula w 1Krn 15,29, choć tym razem jest oparta na źródle 2Sm 6,20-23. W tym miejscu Kronikarz streszcza i parafrazuje tekst Drugiej Księgi Samuela, dodatkowo precyzując pochodzenie Mikal (córka Saula) i komunikując ogólny sens jej reakcji (pogarda) na spontaniczne zachowanie Dawida względem Arki. Co ciekawe, w 15,29 nie cytuje on obszernie zrelacjonowanej w 2Sm 6,20-22 i mało pochlebnej opinii Mikal o Dawidzie ani nie przywołuje informacji o jej dozgonnej bezpłodności, która w 2Sm 6,23 pełni rolę pro-Dawidowego

45 Tekst 1Sm 14,17-19 jest nie do końca zrozumiały. Z jednej strony wprost mówi o arce JHWH $(14,18$ a) i potwierdza jest obecność w tym okresie w Izraelu za pomocą dodatkowej redakcyjnej glosy $(14,18 b)$, a z drugiej sugeruje ryt konsultacji, do którego w tej epoce używano zwykle kapłańskiego efodu oraz losów Urim i Tummim. Dlatego LXX i niektóre przekłady korygują Tekst Masorecki i syntagmę 'ărôn hā'élōhîm zastępują pojęciem efod. 
komentarza do tej sytuacji. W kontekście wcześniej wyrażonej opinii na temat lekceważącego stosunku Saula do Arki Przymierza $(13,3)$ lakoniczna nota o pogardliwej postawie Mikal wobec Dawida ma zasugerować lektorowi księgi, że cały ród jego poprzednika nie dbał o cześć należną najświętszemu przedmiotowi kultu w Izraelu.

Tej surowej opinii Kronikarza o braku pobożności Saula w pewnym stopniu przeczy też treść wiersza 26,28. Prezentując z perspektywy własnej epoki kapłańską i lewicką służbę w jerozolimskiej świątyni, którą - w opinii Kronikarza - zaaranżował już Dawid oddany całym sercem temu sanktuarium $(23,1-26,32)^{46}$, wiersz 26,28 wylicza stróżów świątynnego skarbca oraz złożone w nim łupy wojenne i dary. Wśród ofiarodawców jako pierwszego wymienia oczywiście Dawida i jego wodzów (26,26b-27), ale zaraz potem mówi o Samuelu i Saulu, synu Kisza, a także jego dowódcy - Abnerze (26,28; por. 2Sm 3,6-39), co wskazywałoby na to, że królewski dwór Saula pamiętał o Bogu i troszczył się o Jego miejsca kultu (i Arkę Przymierza).

Aby zamknąć kronikarską opinię o Saulu, trzeba przywołać jeszcze tekst 10,1-14, który jest najobszerniejszym i najważniejszym świadectwem o pierwszym władcy Izraela w Pierwszej Księdze Kronik. Passus ten odzwierciedla materiał źródłowy 1Sm 31,1-13, a zarazem nosi na sobie poważne ślady literackiej i ideowo-teologicznej elaboracji Kronikarza, dlatego może służyć jako reprezentatywny wzorzec jego historiograficznej metodologii stosowanej w procesie elaboracji oryginalnych tradycji, a zarazem ewidentny przykład pro-Dawidowej lektury dziejów Izraela.

46 T. C u d w or th, The Davidic "Heart" for the Temple in Chronicles, CBQ 81 (2019) nr 2, s. 204-216. 


\section{Kronikarska wizja śmierci Saula i jej konsekwencji (1Krn 10,1-14)}

Z punktu widzenia krytyki tekstu, wersja zdarzeń w 10,1-12 odwzorowuje źródło $1 \mathrm{Sm} 31,1-13^{47}$ i nie przedstawia poważniejszych problemów interpretacyjnych, choć już na pierwszy rzut oka widać, że Kronikarz w kilku miejscach odchodzi od oryginału, koryguje go i uzupełnia, aby ten epizod dokładnie dopasować do literackiego i teologicznego profilu dzieła. Natomiast epilog perykopy $(10,13-14)$ jest już oryginalną inwencją Kronikarza, która nie znajduje paraleli w innych biblijnych źródłach. ${ }^{48}$ Wiersze te mają formę teologicznego komentarza sugerującego powody tragicznego upadku Saula i przejęcia władzy królewskiej przez Dawida.

To, co uderza już w trakcie wstępnej lektury 10,1-14 na tle pozostałych tekstów o Saulu w Pierwszej Księdze Kronik, to niespotykana dotąd atencja, z jaką Kronikarz podchodzi do źródłowego opisu jego śmierci. Z panoramy omówionych wyżej tekstów jasno wynika, że na żadnym szczególe z życia króla nie skupił się w takim stopniu, jak na okolicznościach i przyczynach dramatycznej klęski w bitwie na wzgórzu Gilboa. Aby zrozumieć zakres i charakter kronikarskiej relektury 1Sm 31,1-13, trzeba zwrócić baczną uwagę na istotne różnice (zaznaczone rozstrzeleniem ) między tymi dwoma tekstami. Zamieszczony niżej przekład hebrajskiej wersji 1Krn 10,1-14, opatrzony

47 Kronikarz w kilku miejscach uzupełnia tekst 1Sm 31,1-13, ale dokładne zestawienie tych dwu tradycji sugeruje, że prawdopodobnie korzystał z hebrajskiej wersji epizodu 1Sm 31,1-13, która była nieco krótsza od tej, którą zachowali Masoreci; G. K n o p p e r s, 1Chronicles 1-29, s. 516.

48 E. C u r ti s, A. M a d s e n, A Critical and Exegetical Commentary, s. 184; H. W i 11 i a m s o n, 1 and 2 Chronicles, NCBC, Eerdmans, Grand Rapids 1982, s. 93; S. Z a l e w s k i, The Purpose of the Story of the Death of Saul in 1Chronicles X, VT 39/1989, s. 449-467; C. H o, Conjectures and Refutations. Is 1Samuel XXXI 1-13 Really the Source of 1Chronicles X 1-12? VT 45/1995, s. 82-106; A. H i 11 , $1 \& 2$ Chronicles, NIVAC, Zondervan, Grand Rapids 2003, s. 196. Warto zauważyć, że w swej rekonstrukcji zdarzeń Kronikarz pomija zupełnie drugą źródłową wersję wypadków z Gilboa zapisaną w 2Sm 1,1-16. 
odpowiednim aparatem krytycznym, obrazuje różne aspekty literackiej i teologicznej elaboracji Kronikarza, której celem było dostosowanie pierwotnego źródła do proponowanej w Pierwszej Księdze Kronik koncepcji rządów Saula i Dawida.

${ }^{1}$ Filistyni walczyli z Izraelem, a mężowie izraelscy uciekli przed Filistynami i padli przebici na wzgórzu Gilboa. ${ }^{2}$ Filistyni natarli na Saula i na jego synów, i pobili Jonatana, Abinadaba i Malkiszuę, synów Saula. ${ }^{49}{ }^{3}$ I bitwa stała się ciężka dla Saula. Wytropili go łucznicy z łukami i został zraniony przez łuczników. ${ }^{50}{ }^{4}$ I powiedział Saul do swego giermka: «Dobądź twego miecza i przebij mnie nim, żeby nie przyszli ci nieobrzezani ${ }^{51}$ i nie naigrawali się ze mnie». Ale giermek nie chciał [tego uczynić], gdyż bardzo się bał. A Saul dobył miecza i rzucił się na niego. ${ }^{5}$ I zobaczył giermek, że Saul umarł, i także on rzucił się na miecz i umarł. ${ }^{52} 6$ I umarł Saul, i trzej jego synowie, i c ały dom je g o ${ }^{53}$ zginął razem z nim. ${ }^{7}$ Kiedy w s z y s c y ${ }^{54}$ mężowie Izraela, [kt ó r z y b y 1 i]

49 Kronikarz idzie tu za oryginałem (1Sm 31,2), a odchodzi od własnej genealogii synów Saula, która jest następująca: „Jonatan, Malkiszua, Abinadab i Eszbaal” (1Krn 8,33; 9,39). Wersja 1Sm 14,49 czyta z kolei: „Jonatan, Jiszwi i Malkiszua”. Iszwi to prawdopodobnie Iszbaal (Iszboszet), o którym mowa w 2Sm 2,8.

50 Tekt Masorecki 1Sm 31,3b (wajjāhel me'ōd mēhammôrîm) i 1Krn 10,3b (wajjāhel min-hajjôrîm) mają lekcję: ,i zadrżał (bardzo) wobec łuczników”. Podobnie w 1Sm 31,3b czyta LXX: kai etraumatisthe. Z kolei wersja LXX 1Krn 10,3b sugeruje lekcję: kai eponesen apo tōn toksōn - ,i został zraniony od łuków [łuczników]”.

51 Tekt Masorecki i LXX 1Sm 31,4 w tym miejscu dodają: ûdeqārûnî - „nie przebili mnie".

52 Tekt Masorecki i LXX 1Sm 31,5 w tym miejscu dodają: 'immô - ,z nim”.

53 Kronikarz opuszcza wyrażenie: wenōśé' kēlājw „, jego giermek” (1Sm 31,6b) i radykalnie modyfikuje masorecką wersję ostatniej części wiersza. Źródło 1Sm 31,6b czyta: gam kol-'ănāšājw bajjôm haĥ̂' jahdāw - ,[i zginęli] też wszyscy mężowie w tym dniu razem $\mathrm{z}$ nim". LXX ${ }^{\mathrm{L}}$ opuszcza ten fragment, mówiąc tylko o śmierci giermka, a 1Krn 10,6b ma: wekol-bêtô jaḥdāw mēt $\hat{u}$ - „, zginął cały jego dom razem z nim".

54 1Sm 31,7 w tym miejscu proponuje lekcję: wajjir' $\hat{u}$ 'ănšêe-jiśrā'ēel-,,i zobaczyli mężowie Izraela”, ale Kronikarz w 10,7 czyta: wajjir' û kol-'îš jiśrāèel-, „i zobaczyli wszyscy mężowie Izraela”. 
w dolinie ${ }^{55}$ s postrzegli, że [tamci] uciekli, ${ }^{56}$ i że poległ Saul i jego synowie, opuścili swe miasta i uciekli. I nadeszli Filistyni i zamieszkali w nich. ${ }^{8}$ I zdarzyło się następnego dnia, że przyszli Filistyni złupić pobitych i znaleźli Saula i jego s y nó w, ${ }^{57}$ poległych na wzgórzu Gilboa. ${ }^{9}$ I złupili go, i ponieśli jego głowę izbroję. ${ }^{58}$ Po całej ziemi filistyńskiej rozesłali polecenie, aby obwieścić nowinę swoim bogom ${ }^{59}$ i ludowi. ${ }^{10}$ Zbroję jego zło ż y 1 i w św iąty n i s wo i ch bogów, a czaszkę jego przytwierdzili w ś w i ąt y n i Da g o na. ${ }^{60}{ }^{11}$ Gdy w s z y s c y ${ }^{61}$ mieszkańcy Jabesz-Gilead usłyszeli o wszystkim, co Filistyni uczynili Saulowi, ${ }^{62}{ }^{12}$ powstali wszyscy dzielni mężowie, ${ }^{63}$

55 1Sm 31,7 czyta w tym miejscu: „,ci którzy [byli lub zamieszkiwali] po drugiej stronie doliny i po drugiej stronie Jordanu".

56 Podmiot zdania w tym fragmencie masoreckiej wersji 10,7 jest ambiwalentny i nie pozwala precyzyjnie określić, kto ucieka przed Filistynami. Hebrajska składnia Kronikarza sugeruje, że uciekającym jest Saul i jego synowie, ale żadne biblijne źródło nie potwierdza tej opinii. LXX precyzuje, że uciekającym jest Izrael (efygen Israēl), na co wskazuje też treść 1Krn 10,1 i 1Sm 31,7: nāsû 'ănšêe-jiśrā'ēl-,uciekli mężowie Izraela".

57 1Sm 31,8 czyta w tym miejscu: we'et-šelōšet bānājw - „, trzech jego synów”.

58 Materiał źródłowy 1Sm 31,9 czyta tu: wajjikretû 'et-rō'šô wajjapšîtû 'etkēlājw - „, odcięli jego głowę i zdarli jego zbroję”. Informacji o dekapitacji Saula brakuje w LXX ${ }^{\mathrm{AB}}$, co wyraźnie sugeruje, że wersja $1 \mathrm{Sm}$ 31,7 i nieco odmienna od niej lekcja 1Krn 10,9 odzwierciedlają wspólne źródło o profanacji zwłok króla.

59 Tekst Masorecki, Peszitta i niektóre Targumy w $1 \mathrm{Sm}$ 31,9b sugerują nieco odmienną lekcję: lebaśśēer bêt 'ășabbêhem we'et-hā'ām - ,aby obwieścić nowinę w świątyni swych bogów i ludowi”. Kronikarz pomija informację o świątyni być może dlatego, że będzie o niej mówił w 10,10.

60 Tekst Masorecki i LXX 1Sm 31,10 brzmią inaczej: wajjāśimû 'et-kēlājw bêt 'aštārôt we'et-gewijjātô tāq' $\hat{u}$ behômat bêt šān - „I złożyli jego zbroję w świątyni Asztarty, a ciało przytwierdzili na murze w Bet-Szean".

${ }_{61}$ Tekst Masorecki, LXX, Peszitta, Vulgata i wiele manuskryptów 1Sm 31,11 opuszczają: $k \bar{o} l-$, ,wszyscy”.

${ }^{62}$ LXX dodaje: kai tōi Israēl - „i Izraelowi”.

${ }^{63}$ Tekst Masorecki 1Sm 31,12 dodaje w tym miejscu: wajjēlkû kol-hallajlâ,i szli przez całą noc”. 
a zabrawszy ciało Saula i ciała jego synów, ${ }^{64}$ sprowadzili je do Jabesz ${ }^{65} i^{66}$ pochowali kości ich p o d t e r e b i n t e m w Jabesz. I pościli przez siedem dni. ${ }^{13} \mathrm{Sau} 1 \mathrm{umar} \nmid \mathrm{przez}$ swą niewierność, którą zawinił wobec JHWH, i z uwagi na słowo JHWH, którego nie przestrzegał, a także [ze względu na to], że konsultował ducha zmarłego, by się go radzić. ${ }^{67}{ }^{14} \mathrm{~A}$ nie radził się JHWH. I sprawił [JHWH], że umarł, a królestwo przeniósł na Dawida, syna Jessego".

Pierwsza istotna różnica między 1Krn 10,1-14 a 1Sm 31,1-13 pojawia się w wersie 10,6, który opisuje rozmiary militarnej porażki wojsk Saula. Nawiązując do dramatycznej relacji o samobójczej śmierci króla (10,4-5; por. 1Sm 31,4-5), Kronikarz zdecydowanie odchodzi od świadectwa źródeł (1Sm 31,2; 2Sm 1,1-12; por. 1Krn 10,2) informując, że na wzgórzu Gilboa z rąk Filistynów poległ Saul, trzej jego synowie i wszyscy członkowie jego rodu. ${ }^{68}$ Wyrażenie kol-bêtô (,,cały jego dom"), wpisane przez Kronikarza w kontekst 10,6 w miejsce informacji o giermku (por. 1Sm 31,6b), w tradycjach o Saulu i Dawidzie oznacza tych, którzy zwykle tworzą najwyższe kręgi królewskiego dworu (synowie i najbliżsi krewni władcy), a więc są

${ }^{64}$ Tekst Masorecki i LXX w tym fragmencie 1Sm 31,12 dodaje: mēhômat bêt šān-, ,z muru w Bet-Szean”.

${ }_{65}$ Tekst Masorecki, Peszitta i LXX w 1Sm 31,12b dodaje: wajjiśrepû 'ōtām $\check{s} \bar{a} m-$, , i tam je spalili”.

${ }^{66}$ Te informacje redaktor Pierwszej Księgi Samuela umieszcza już w ostatnim wierszu perykopy $(31,13)$, który od $1 \mathrm{Krn} 10,12 \mathrm{~b}$ różni się tylko miejscem pochówku: tahat-hā'ešel bejābēša - „pod tamaryszkiem w Jabesz”.

${ }^{67}$ LXX dodaje: kai apekrinato autōi Samouēl ho profetek - „i odpowiedział mu prorok Samuel".

${ }^{68}$ I ta kronikarska wersja wydarzeń pozostaje w sprzeczności z tradycjami $2 \mathrm{Sm}$ 2,8-4,2; 9,1-13; 21,1-14, które mówią o synach Saula w kontekście rywalizacji o tron królewski z Dawidem. Kronikarz opuścił lub ideowo skorygował wszystkie źródłowe passusy (2Sm 2,1-4,12; 9,1-13; 21,1-14), aby zatrzeć ślady o krwawej wojnie o tron, jaka rozegrała się po śmierci Saula między obozem Dawida i Beniaminitami. 
społeczno-politycznym i militarnym zapleczem i siłą monarchy, a także decydują o następcy tronu (por. 2Sm 3,1; 7,11-13.16.25; 9,9; 15,16; 19,12.42). Celem kronikarskiej ingerencji w źródłowy przekaz 10,6 jest definitywne zamknięcie epoki rządów Saula i Beniaminitów w Izraelu. Dlatego też informację o śmierci urzędującego władcy i jego synów wzmacnia notą o zagładzie kręgu ich sojuszników, która ostatecznie przekreśliła szanse na utrzymanie przez klanowy i polityczny obóz (dom) Saula wpływów w Izraelu i stworzenie dynastii królewskiej. Według takiej rekonstrukcji dziejów, natychmiast po śmierci Saula (por. 10,13-14; 11,1-3) otworzyła się droga do przejęcia władzy przez Dawida i jego dom (por. 1Krn 17,23). ${ }^{69}$

Powodów tej społeczno-politycznej transformacji w Izraelu, zdaniem Kronikarza, było wiele, o czym wprost mówi w glosie dodanej do opracowywanego źródła $(10,13-14)$ i otwarciu kolejnej sekcji dzieła (11,1-3). Jednym z nich była militarna słabość Saula, która dała o sobie znać za jego rządów (por. 11,2), a szczególnie w decydującej fazie konfrontacji z Filistynami na wzgórzu Gilboa. I w tym właśnie kluczu Kronikarz interpretuje źródłowy tekst 1Sm 31,7 w wierszu 10,7. Wiele wskazuje na to, że ambiwalentna treść i składnia 1Krn 10,7 jest zamierzona przez redaktora, który, korygując tekst źródła, postanowił zasugerować, że to nie „mężowie Izraela” (1Sm 31,7b), lecz Saul i jego synowie uciekali przed śmiercią z pola walki. Ostatecznie i tak nie uniknęli klęski, a swą niechlubną postawą sprowokowali ucieczkę mieszkańców całego regionu (doliny) i zajęcie tych terenów przez Filistynów. ${ }^{70}$ Ta arbitralna ocena nie znajduje potwierdzenia w biblijnych

69 U. B e r g e s, Die Verwerfung Sauls, s. 277-278; G. B o t t e r w e c k, Zur Eigenart der chronistischen Davidgeschichte, TQ 136/1956, s. 403. Według materiału źródłowego z Drugiej Księgi Samuela, „,dom Saula” nie uległ całkowitej zagładzie na wzgórzu Gilboa. Wielu jego członków po tej klęsce miało aspiracje, by nadal ubiegać się o władzę, co nakręciło spiralę politycznych intryg i przemocy aż do momentu namaszczenia Dawida na króla (2Sm 2,1-4,12). Zresztą, walka Beniaminitów o społeczno-polityczne wpływy w Izraelu trwała jeszcze przez cały czas rządów syna Jessego (2Sm 9,1-13; 16,5-14; 21,1-14).

70 H. S to e b e, Das erste Buch Samuelis, KAT 8.1, Evangelische Verlag, Gütersloh 1973, s. 529. 
źródłach, ${ }^{71}$ a wpisuje się w pro-Dawidową relekturę historii Saula, która miała skompromitować Saula i podważyć militarną renomę jego sojuszników. ${ }^{72}$

Serię niewielkich korekt zauważa się też w kronikarskiej wersji profanacji ciała Saula i jego pogrzebu $(10,8-12) .{ }^{73}$ Pierwszą różnicą w odniesieniu do źródłowego 1Sm 31,8 widać w 10,8b. Kronikarz porzuca precyzyjny zapis źródła: we'et-šelōšet bānājw - „i trzech jego synów” i celowo go uogólnia: we'et-bānājw - „i jego synów”, by raz jeszcze (por. kol-bêtô - „cały jego dom” w 10,6) zasugerować zagładę rodu Saula, ${ }^{74}$ a w perspektywie rozpoczynającej się historii Dawida $(11,1-29,30)$ dać do zrozumienia, że na Gilboa zginęli wszyscy ewentualni pretendenci do tronu z rodu Beniamina. Niewielkiej elaboracji poddał też opis profanacji ciała monarchy. Mówiąc o zdarciu zbroi ze zwłok Saula, wspomina też o zabraniu jego głowy, choć nie mówi, jak 1Sm 31,9a, o jej ścięciu. Do zbroi i głowy króla, w nieco innym niż 1Sm 31,10 kontekście, powraca raz jeszcze w 10,10. 1Sm 31,9-10 mówi o dekapitacji Saula, ale nie informuje o losie jego głowy. Powiadamia natomiast o tym, że zbroja króla znalazła się w świątyni Asztarty, a jego ciało zawisło na murze w Bet-Szean. Korzystając w tym miejscu prawdopodobnie z innego źródła, Kronikarz informuje

71 Zamieszczony wyżej aparat krytyczny do 1Krn 10,7 (LXX) i 1Sm 31,7 mówi, że z pola bitwy uciekli (uciekali) obecni tam Izraelici, a nie Saul i jego synowie, którzy walczyli do ostatka i polegli na placu boju.

72 W tym właśnie kontekście można najłatwiej zrozumieć motyw, dla którego Kronikarz rozszerzył źródło 1Sm 31,7a o słowo kol (,wszyscy”): wajjir' $\hat{u}$ kol-' $\imath \hat{s}$

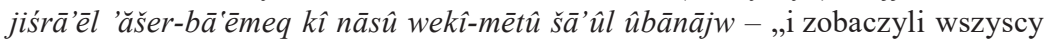
Izraelici, którzy [byli, mieszkali] w dolinie, że uciekali i polegli Saul i jego synowie". Zgodnie z jego rekonstrukcją zdarzeń, ucieczka, a potem śmierć króla i jego synów była faktem ogólnie znanym w Izraelu. Echem tego negatywnego osądu w strukturze księgi jest głos Izraelitów przywołany w kolejnej perykopie $(11,2)$.

73 Co ciekawe, Kronikarz nie ingeruje w żaden sposób w opis ostatnich chwil życia króla Saula i jego samobójczej śmierci, zachowując w całości jego oryginalne brzmienie (por. $1 \mathrm{Sm}$ 31,3-5 i 1Krn 10,3-5).

74 Niewykluczone, że tą korektą źródła Kronikarz pragnie też przywołać zapowiedź Samuela z konsultacji w En-Dor, w której zwiastuje śmierć Saula i jego synów w potyczce z Filistynami (1Sm 28,19). 
z kolei, że zbroja Saula znalazła się w świątyni filistyńskiej, a czaszka (gulgōlet) w sanktuarium Dagona. Z uwagi na brak innych źródeł trudno ustalić, która $\mathrm{z}$ tych dwu wersji jest historycznie poprawna, można zauważyć tylko, że Kronikarz nie zajmuje się ciałem Saula, tylko jego głową i zbroją, które w rękach Filistynów były uważane za dowód i symbol odniesionego zwycięstwa oraz wotum dla bogów. Aż dwa anonimowe miejsca kultu filistyńskiego w 10,7 to kolejny znak ideowo-teologicznej elaboracji 1Sm 31,1-13, mającej na celu profanację królewskiej godności i urzędu Saula, a zarazem pochwałę Dawida. Mówiąc o złożeniu głowy i zbroi Saula w anonimowych świątyniach Filistynów, Kronikarz przywołuje bowiem analogiczny los głowy i zbroi Goliata, które jako łup wojenny zostały przyniesione przez Dawida do Jerozolimy (1Sm 17,54). Tym samym Kronikarz zrównuje los Saula z losem Goliata, a Dawida w kontekście wojny Izraela z Filistynami ukazuje jako pogromcę najbardziej doświadczonego z wojowników wroga (por. 1Sm 17,1-58; 2Sm 21,19; 1Krn 20,5), już na tym etapie narracji zapowiadając wypełnienie misji powierzonej przez JHWH synowi Kisza (1Sm 9,16; 2Sm 5,17-25; 1Krn 14,8-17).

Ostatnia korekta źródła dotyczy szczegółów opisu pochówku króla. W zestawieniu z 1Sm 31,11-13, Kronikarz akcentuje powszechny udział obywateli Jabesz-Gilead w pogrzebie Saula (10,11a), opuszcza natomiast informację o spaleniu zwłok Saula i jego synów, ${ }^{75}$ i gdzie indziej sytuuje miejsce złożenia ciała: tahat-hā'elâ bejāběš -,,pod terebintem w Jabesz" (10,12b).

Najwięcej uwagi egzegetów przykuwa jednak obszerny epilog tej perykopy (10,13-14), który w całości jest inwencją Kronikarza. Utrzymany jest w tonie teologicznego komentarza i wpisuje się w całości w jego pro-Dawidową (anty-Saulową) strategię narracyjną, ukazując śmierć pierwszego króla Izraela w kluczu Bożego gniewu i kary. Od razu trzeba podkreślić surowy ton tej oceny. Nawet pro-Dawidowa deuteronomistyczna rekonstrukcja rządów Saula (1Sm 9-31), która jego odrzucenie i śmierć jako pierwsza wyraźnie wpisała w schemat

${ }^{75}$ Notę wajjiśrepu 'ôtām šām - „, tam je spalili’” (1Sm 31,12b) zawierają: Tekst Masorecki, Peszitta i LXX. 
realizującej się wyroczni Samuela potępiającej nieposłuszeństwo władcy (1Sm 13,11-15; 15,10-29; 28,15-19), nie odczytuje jego klęski wprost w kategorii śmiercionośnej woli JHWH. ${ }^{76}$ Opis śmierci Saula i jego synów w 1Sm 31,1-13 i 2Sm 1,1-27 jest ukazany w mocno ambiwalentnym świetle. $Z$ jednej strony lektor wie, że ten tragiczny los jest owocem wcześniejszego Bożego i prorockiego odrzucenia, ale z drugiej do samego końca jest świadkiem bohaterstwa i poświęcenia Saula oraz jego wierności wobec misji, jaką otrzymał od JHWH w chwili wyboru na króla. Pozytywny ton oceny Saula nieśmiało rozbrzmiewa więc w tle opisu jego śmierci $(31,1-13)$ i wprost dochodzi do głosu w opinii wyrażonej przez Dawida w 2Sm 1,1-27.

Kronikarz porzuca ten nurt interpretacji i w swej autorskiej, jasno zdefiniowanej, opinii zdobywa się na bezwzględną krytykę króla. W kluczu struktury wyroczni prorockiej, najpierw definiuje jego winę $^{77}$ (10,13-14a), a potem mówi o Bożej karze, którą JHWH aplikuje osobiście (10,14b). Obszerna lista win Saula i rzadki w Biblii motyw bezpośredniego zaangażowania się JHWH w wymierzenie mu najwyższej kary (śmierć winowajcy), akcentują naganność postawy władcy, a zarazem sprawiedliwość i nieodwołalność Bożego wyroku. Wina Saula jest określona rzadkim w Biblii Hebrajskiej rdzeniem

76 Tego rodzaju opinię widać natomiast w deuteronomistycznym opisie śmierci najbardziej niegodziwych i bałwochwalczych władców Izraela (Sdz 9,56-57; 1Krl 21,19-24; 22,17-23.38).

77 Rdzeń $m^{\imath} l$ nie jest terminem teologii deuteronomicznej, a deuteronomista używa go tylko w odniesieniu do winy Akana (Joz 7,1; 22,20). Kronikarz określa w ten sposób tylko winę Akara, syna Karmiego, który popełnił czyn analogiczny do Akana (1Krn 2,7), bałwochwalcze praktyki rodu Manassesa (1Krn 5,25-26), postawę Saula (1Krn 10,13), świętokradztwo króla Ozjasza w jerozolimskiej świątyni (2Krn 26,16.18) i politykę synkretyzmu religijnego i moralnej deprawacji Achaza (2Krn 28,19.22; 29,19) i Manassesa (2Krn 33,19). Tym rdzeniem opisuje też nieczystość rytualną i niemoralność ludu Judy i jego społeczno-religijnych liderów, która sprowokowała Boży gniew, najazd Babilończyków oraz upadek monarchii i świątyni (1Krn 9,1; 2Krn 29,6; 30,7; 36,14). W tle ukazanej tym terminem winy Saula oraz grzechu ludu i przywódców Judy pojawia się dodatkowo wątek nieposłuszeństwa wobec słowa Boga i urzędu proroka (1Krn 10,13-14; 2Krn 36,15-16). 
$m^{\imath} l$ (,,być /stawać się/ niewiernym, zawodzić”), ${ }^{78}$ który sugeruje złamanie zawartego wcześniej przymierza (niedotrzymanie warunków umowy wobec Boga lub człowieka) skutkujące nieodwracalnym zerwaniem relacji (Lb 5,12.19-29; Hi 21,34). W 10,13-14 Kronikarz ma na myśli zerwanie więzi z Bogiem powstałej w chwili jego wyboru i namaszczenia (1Sm 9,1 - 10,16; 11,1-15), które spowodowało zawiązanie analogicznej relacji między JHWH a Dawidem (1Sm 16,1-13). Krytyczna opinia Kronikarza ma charakter ogólny i zdaje się wypływać z lektury 1Sm 9,1-31,13. Formułując zarzuty wobec króla, w 10,13-14 wprost odnosi się tylko do rytu nekromancji w En-Dor (10,13b-14a; 1Sm 28,3-25). ${ }^{79}$ Zarzucana natomiast Saulowi niewierność wobec JHWH (ma'al) i niewypełnienie Jego słowa (lo'’šāmār) są wyrażone lakonicznie i ambiwalentnie, ${ }^{80}$ tak że można się tylko domyślać, że chodzi tu o epizody opisane w 1Sm 13,7b-15a; 15,1-35. W ocenie życia Saula Kronikarz idzie więc torem wyznaczonym przez pro-Dawidowego redaktora Pierwszej Księgi Samuela, który wkomponował te dwa teksty w oryginalnie pro-Saulowy trzon narracji o pierwszym władcy Izraela i tak je zredagował, by go poważnie obciążyć i usprawiedliwić przejęcie władzy przez Dawida. ${ }^{81} \mathrm{~W} 10,13-$ -14 Kronikarz zdaje się przywoływać te same tradycje o sporze Saula

78 R. Knieri m, mil, w: E. Je n n i, C. We s ter m a n n (red.), Theological Lexicon of the Old Testament, t. 2, Kaiser Verlag, München 2004, s. 481-482; H. R in g g re n, $m^{\prime} l$, w: G. B o t t e r w e c k, H. R in g g r e n, H. F a b r y, Theological Dictionary of the Old Testament, t. 8, Eerdmans, Grand Rapids 1997, s. 461-463.

79 Grecka LXX wprost podkreśla zależność 1Krn 10,13b od 1Sm 28,3-25 dodając: kai apekrinato autōi Samouel ho profetek - ,i odpowiedział mu prorok Samuel”.

80 Forma i treść 10,13-14 dowodzą, że celem Kronikarza nie było historyczne udokumentowanie winy Saula, lecz ideowo-teologiczna ocena pierwszego władcy Izraela, która ukazywałaby go jako wiarołomnego króla zrywającego bliską relację z Bogiem oraz niweczącego własne wyniesienie i zleconą sobie misję.

81 D. M c C a r t h y, Hero and Anti-Hero in 1Sam 13,2 - 14,46, w: t e n ż e (red.), Institution and Narrative. Collected Essays, AnBib 108, Roma 1985, s. 252; A. P o p o v i c, Saul's Fault in 1Sam 13,7b-15a. Why Has the First Israelite King Fallen? Antonianum 68/1993, s. 155; A. W e i s e r, 1Samuel 15, ZAW 54/1936, s. 1-28; H. D o n n e r, Die Verwerfung des Königs Sauls, w: t e n ż e (red.), Aufsätze zum Alten Testament, BZAW 224, de Gruyter, Berlin 1994, s. 144-146. 
z Samuelem, by uzasadnić śmierć króla w kluczu teologicznej zasady Bożej retrybucji, na której opiera się historiografia biblijna.

Inaczej traktuje tylko fakt nekromancji. W 10,13b-14a poświęca mu najwięcej miejsca, tak że urasta do miana głównego oskarżenia i bezpośredniej przyczyny gniewu Bożego, którego skutkiem jest śmierć Saula i utrata władzy królewskiej. W tej kwestii Kronikarz tylko po części odwołuje się do źródeł (1Sm 28,3-25), choć nie podziela ich neutralnej opinii na temat samego rytu, ${ }^{82}$ a co ważniejsze, w trzonie swej krytycznej oceny otwarcie im zaprzecza. Sugerując, że Saul konsultował się z nekromantami (wegam-liš' ôl bā'ôb lidrôš welō'-dāraš bJHWH), którzy - w roli medium - umożliwiali żywym kontakt z duchami zmarłych, a nie prosił o radę JHWH, pomija teksty 1Sm 14,18-19.36-37.41; 28,6, ${ }^{83}$ przez co znacząco modyfikuje wizerunek władcy ukazany w Pierwszej Księdze Samuela. Przy okazji potępia ryt nekromancji, sugerując, że Saul już samym tym grzechem zasłużył na śmierć. Takiej opinii na próżno szukać w 1Sm 28,3-25 i ściśle związanym z nim tekście 31,1-13, które nie potępiają Saula za wizytę u nekromantki w En-Dor ${ }^{84}$ i nie upatrują w niej przyczyny tak

82 Akt nekromancji w strukturze 10,13-14 zajmuje najwięcej miejsca i to on, w opinii Kronikarza, jest głównym powodem klęski, jaką JHWH sprowadził na Saula.

83 Powyższe tradycje dowodzą, że w trakcie działań zbrojnych Saul, zgodnie ze zwyczajem tamtej epoki (instytucja wojny JHWH), wykorzystał wszystkie okazje i dostępne formy rytualne, by wejść w kontakt z Bogiem i zapewnić swemu wojsku Jego wsparcie w walce z Filistynami. Wszystkie próby okazały się jednak nieskuteczne.

84 1Sm 28,3 mówi wprost o reformatorskiej aktywności Saula, której skutkiem było usunięcie wszystkich nekromantów ('ōbôt) i wróżbitów (jidde'ōnîm) z Izraela, a 1Sm 28,5-6 sugeruje, że wizyta u nekromantki w En-Dor była podyktowana bezpośrednim zagrożeniem ze strony Filistynów i nieskutecznością dozwolonych form dywinacji. Kronikarz zupełnie pomija te fakty, oceniając czyn Saula według religijnych norm własnej epoki (por. Pwt 18,9-14; 1Sm 15,23; Kpł 20,27). Nie zastanawia się przy tym, jak to się stało, że Bóg milczał na wszystkie dozwolone rytualnie próby konsultacji, a odpowiedział Saulowi przez Samuela u nekromantki (por. Syr 46,20). 
wielkiego gniewu JHWH. ${ }^{85}$ I w tej materii ocena Kronikarza jest dość arbitralna i wpisuje się w jego wizję narodzin monarchii w Izraelu. Aby oczyścić Dawida z zarzutów nieuprawnionego przejęcia władzy, które pojawiają się w tle Pierwszej i Drugiej Księgi Samuela, przed rekonstrukcją jego rządów w Pierwszej Księdze Kronik (11,1-29,30) naciska na winę poprzednika, stwierdzając wprost, że zarówno jego śmierć, jak i wyniesienie na tron królewski syna Jessego były aktem woli JHWH: wajemîtêhû wajjassēb 'et-hammelûkâ ledāwîd ben-jišāj. ${ }^{86}$

Wiersze 10,13-14 nie mają statusu historycznego sumarium podsumowującego rządy Saula, lecz są ich ideowo-teologiczną oceną podporządkowaną historiograficznym założeniom pro-Dawidowego Kronikarza. Orędzie 10,13-14 należy do najsurowszych biblijnych weryfikacji osoby i aktywności króla i zrównuje Saula z tak negatywnymi władcami Izraela i Judy, jak: Abimelek (Sdz 9,1-58), Jeroboam I (1Krl 11,14 - 14,20), Achab (1Krl 16,29 - 22,40), Achaz (2Krl 16,1-20) czy Manasses (2Krl 21,1-18). Stanowiąc dopełnienie opisu śmierci syna Kisza (10,1-12), przy świadomym redakcyjnym pominięciu wszystkich biblijnych źródeł na jego temat (1Sm 9,1 - 31,13), wiersze te w strukturze Kronik tworzą klasyczny przykład antywzorca króla. W ten sposób w kronikarskiej rekonstrukcji dziejów monarchii Judy i Izraela Saul staje się symbolem nieposłusznego i wiarołomnego władcy, który w dramatycznych okolicznościach został pozbawiony przez JHWH urzędu i życia. ${ }^{87}$ Historia upadłego i odrzuconego przez Boga i lud Izraela władcy posłużyła Kronikarzowi za idealną propagandową platformę, po której na scenę wydarzeń wprowadził swą najjaśniejszą figurę epoki królów - Dawida.

85 Deuteronomistyczna historiografia te dwa epizody łączy za pomocą motywu zapowiedzi i wypełnienia prorockiego słowa Samuela, które w historii Saula odgrywa czołową rolę (1Sm 9,15-16.27; 10,1-8.25; 11,14-15; 12,20-25; 13,11-14; 15,1-3.13-29; 28,15-19).

${ }^{86}$ W opinii Kronikarza, śmierć króla na skutek bezpośredniej ingerencji JHWH dotyka jeszcze Jeroboama (2Krn 13,20) i Jorama (2Krn 21,18-19), ale nie dokonuje się w tak haniebnych dla króla okolicznościach.

87 A. Tron in a, Pierwsza Księga Kronik, NKB 10.1, Edycja św. Pawła, Częstochowa 2015, s. 242. 
W jego opinii, syn Jessego to dokładne przeciwieństwo Saula: Boży wybraniec, doskonały wódz akceptowany przez lud Izraela i jego społeczno-religijne elity, który mocą przymierza z JHWH i umowy ze wszystkimi pokoleniami Izraela gwarantuje sukcesy militarne oraz dostatnie i pokojowe rządy w polityczno-religijnym centrum kraju - Jerozolimie. ${ }^{88}$ Według Kronikarza, monarchia w Izraelu rozpoczyna się w tym mieście od Dawida i jego dynastii, ${ }^{89}$ a rządy Saula były w procesie narodzin tej instytucji jedynie niepozornym i mało chwalebnym epizodem, który warto odnotować tylko dlatego, by podkreślić historyczny i źródłowy charakter Kronik oraz zapewnić autoryzację dla rządów syna Jessego i jego potomnych.$^{90}$

$$
* * *
$$

Analiza literackiego i ideowo-teologicznego profilu Pierwszej Księgi Kronik prowadzi do wniosku, że wiodącym celem Kronikarza w procesie redakcji opisu narodzin systemu monarchicznego w Izraelu, który dla Izraelitów epoki Drugiej Świątyni miał być alternatywą dla dokumentacji deuteronomistycznej (1Sm 7,2 - 2Sm 5,5), nie była stricte historyczna rekonstrukcja zdarzeń, lecz ich historiozbawcza relektura zogniskowana wokół figury Dawida i rządów jego dynastii w Jerozolimie. Istotnym elementem tej historiograficznej strategii Kronikarza była anty-Saulowa elaboracja źródeł polegająca na szeroko zakrojonej marginalizacji osoby i działań pierwszego króla Izraela. Ta koncepcja dokumentacji dziejów Saula nie była w żadnym

${ }^{88} \mathrm{~J}$. Tr o t t e r, Reading, Readers and Reading Readers Reading the Account of Saul's Death in 1Chronicles 10, w: M. Gra ha m, S. M c K e n z i e (red.), The Chronicler as Author. Studies in Text and Texture, JSOT.S 263, Sheffield Academic Press, Sheffield 1999, s. 294-310; T. L or e n z i n, 1-2 Cronache. Nuova versione, introduzione e commento, Paoline Editoriali, Milano 2011, s. 111.

89 J. S m it h, 1Chronicles: Focus on King David. A Commentary, Lulu.com 2016, s. 157; R. K 1 e i n, 1Chronicles, s. 44-45.

90 D. D zi a d o s z, Monarcha odrzucony przez Boga i lud. Proces redakcji biblijnych tradycji o Saulu, Wydawnictwo Archidiecezji Przemyskiej, Przemyśl 2006, s. 509. 
razie domeną stylu pracy Kronikarza, gdyż analogiczne przekazy o Dawidzie z Pierwszej i Drugiej Księgi Samuela przejmował prawie w całości i komentował z dużym zaangażowaniem, dołączając także inne źródła. Materiał o Saulu Kronikarz ograniczył świadomie, zachowując z obszernych źródeł (1Sm 9,1 - 31,13) praktycznie tylko opis jego śmierci (1Krn 10,1-12). Co więcej, nawet ten passus poddał znaczącej ideowo-teologicznej modyfikacji mającej sugerować, że bitwa z Filistynami bezpowrotnie zakończyła erę Saulidów w Izraelu. Śmierć Saula, w opinii Kronikarza, nie była jednak nieszczęściem dla Izraela, a tylko kolejną wiarygodną ilustracją zasadności Bożej zasady retrybucji. JHWH - Bóg Izraela, postanowił bowiem sprowadzić śmierć na niewiernego i bałwochwalczego władcę, aby przenieść królewską godność na Dawida i jego dom, który od tej pory aż do kresu monarchii w Izraelu stanie się narzędziem Bożego błogosławieństwa i pokoju.

\section{ks. Dariusz DZIADOSZ}

Słowa kluczowe: Księgi Kronik; Kronikarz; tradycje o Saulu; pro-Dawidowa lektura historii; historiografia deuteronomistyczna

Keywords: Chronicles; the Chronicler; Saul traditions; pro-David reading of the story; deuteronomistic historiography

\section{Between History, Ideology and Theology. Pro-David Reading of the Saul Traditions in 1 Chronicles Summary}

The main purpose of the big part of 1 Chronicles was to convince the Jews in the Second Temple Period that David was the legal ruler of Israel, chosen by YHWH, the whole population, and even by the house of Saul. Reading the text about the next stages of Saul and David's political career in 1 Chronicles 10:1-9:30 one may get the impression that the narration is very selective (cf. 1 Sam 9:1-31:13), that many events are omitted and only those which emphasize the glory of Jesse's son are presented. Analysing those 
texts one may arrive at the conclusion that David was the opposite of his predecessor in each field, and only he was able to guarantee a permanent political and military futurity for Israel. For ideological and theological reasons the Chronicler has castigated Saul and glorified David. In the history presented by him, YHWH always sides with Jesse's son and not with Saul. This point of view justifies the ideological argumentations of the Chronicler whose main purpose was to show the political transformations in Israel in favour of David, although these resulted in the bloody overthrow of Saul's dynasty (2 Sam 2:1-4:12; 21:1-14). Unlike the deuteronomistic history, his vision of the history of the monarchy is completely theological. Historical events and politics were for him a background pointing to the presence of God and His dominant influence on Israel's first two kings. The establishment of the monarchy was for the Chronicler one of the most important milestones in the history of Israel. However, unlike the earlier historians, he did not stress its political, social and military significance, but he evaluated it only from the perspective of God's plan of salvation.

\section{Bibliografia}

A b a d i e P., 1-2 Chroniques, w: R ö m e r T., M a c c h i J., N i h a n C. (red.), Introduction à l'Ancien Testament, Labor et fides, Genève 2004, s. 594-603. A c k royd P., The Theology of the Chronicler, LTQ 8/1973, s. 101-116.

A c k r o y d P., The Chronicler as Exegete, JSOT 2/1977, s. 2-32.

A d a m K., Saul und David in der judäischen Geschichtsschreibung: Studien zu 1 Samuel 16 - 2 Samuel 5, FAT 51, Mohr Siebeck, Tübingen 2007.

A r nold B.T., Samuel, Books of, w: A r nold B.T., W illia m so n H.G. (red.), Dictionary of the Old Testament. Historical Books, InterVarsity Press, Downers Grove-Nottingham 2005, s. 866-877.

$\mathrm{B}$ a $\mathrm{r}$ e $1 \mathrm{~m} \mathrm{u} \mathrm{s}$ R., Heroentum in Israel und seiner Umwelt, ATANT 65, Theologischer Verlag, Zürich 1979.

B e c k e r J., 1 Chronik, NEB 18, Echter Verlag, Würzburg 1986.

B e n z i ng e r I., Die Bücher der Chronik - erklärt, KHCAT 20, J.C. Mohr, Tübingen 1901.

B e $n$ Zv i E., The Book of Chronicles: Another Look, SR 31/2002, s. 261-281. B e r g e s U., Die Verwerfung Sauls. Eine thematische Untersuchung, FzB 61, Echter Verlag, Würzburg 1989.

B e z z e 1 H., Saul: Israels König in Tradition, Redaktion und früher Rezeption, FAT 1.97, Mohr Siebeck, Tübingen 2015. 
B e z ze 1 H., Saul und die Philister: Redaktionskritische Überlegungen zu 1 Samuel 13-14, w: D i e tri c h W., The Books of Samuel. Stories - History-Reception History, BETL 284, Peters, Leuven 2016, s. 457-466.

B o t t e rwe ck G., Zur Eigenart der chronistischen Davidgeschichte, TQ 136/1956, s. 402-435.

B r a u n R., 1Chronicles, WBC 14, Word Books, Waco 1986.

C a r 1 s o n R., David the Chosen King. A Traditio-Historical Approach to the Second Book of Samuel, Almqvist \& Wilksell, Stockholm 1964.

C og g in s J., The First and Second Books of the Chronicles, CBC, Cambridge University Press, Cambridge 1976.

$\mathrm{Cudw}$ or th T., War in Chronicles. Temple Faithfulness and Israel's Place in the Land, Oxford 2014.

Cudworth T., The Davidic "Heart" for the Temple in Chronicles, CBQ 81(2019) nr 2, s. 204-216.

$\mathrm{Cu} \mathrm{rt}$ is E., Mad s e n A., A Critical and Exegetical Commentary on the Books of Chronicles, T\&T Clark, Edinburgh 1994.

D i t trich W., David, Saul und die Propheten. Das Verhältnis von Religion und Politik nach den prophetischen Überlieferungen vom frühesten Königtum in Israel, BWANT 122, Kohlhammer, Stuttgart 1987.

D i e t r i c h W., 1 Samuel 1-12, BKAT 8.1, Neukirchener Verlag, Neukirchen-Vluyn 2011.

D o c k e r y H., Holman Concise Bible Commentary, Broadman \& Holman Publishers, Nashville 1998.

D o n n e r H., Die Verwerfung des Königs Sauls, w: t e n ż e (red.), Aufsätze zum Alten Testament, BZAW 224, de Gruyter, Berlin 1994, s. 133-164.

D z i a d o s z D., Monarcha odrzucony przez Boga i lud. Proces redakcji biblijnych tradycji o Saulu, Wydawnictwo Archidiecezji Przemyskiej, Przemyśl 2006.

E d e n bu rg C., P a k k a la J. (red.), Is Samuel among the Deuteronomist? Current Views on the Place Samuel in a Deuteronomistic History, SBL 16, Society of Biblical Literature, Atlanta 2013.

E is s feld t O., The Old Testament, an Introduction, Harper \& Row, New York 1965.

F o r e s $t$ i F., The Rejection of Saul in the Perspective of the Deuteronomistic School. A Study of 1 Sam 15 and Related Texts, STT 5, Edizioni del Teresianum, Rome 1984.

G a b r i e 1 I., Friede über Israel. Eine Untersuchung zur Friedenstheologie in Chronik I 10 - II 36, OBS 10, Österreichisches Katholisches Bibelwerk, Klosterneuburg 1990.

G a lb i a t i E., S e r a f i n i F., Historyczny atlas Biblii, Jedność, Kielce 2006. 
Gertz J., Witte M., Schmid K. (red.), Die deuteronomistischen Geschichtswerke, BZAW 365, de Gruyter, Berlin 2012.

$\mathrm{Gr}$ a h a m M., The Utilization of 1 and 2 Chronicles in the Reconstruction of Israelite History in the Nineteenth Century, SBLDS 116, Scholars Press, Atlanta 1990.

He in r i h A., David und Klio. Historiographische Elemente in der Aufstiegsgeschichte Davids und im Alten Testament, BZAW 401, de Gruyter, Berlin 2009.

H i 11 A., 1 \& 2 Chronicles, NIVAC, Zondervan, Grand Rapids 2003.

H o C., Conjectures and Refutations. Is 1Samuel XXXI 1-13 Really the Source of 1Chronicles X 1-12, VT 45/1995, s. 82-106.

I s h i d a T., The Royal Dynasties in Ancient Israel. A Study on the Formation and Development of Royal-Dynastic Ideology, BZAW 142, de Gruyter, New York 1977.

J a n z e n D., Chronicles and the Politics of Davidic Restoration. A Quiet Revolution, T\&T Clark, Bloomsbury 2017.

K a i s e r O., Der historische und der biblische König Saul (Teil I), ZAW 122(2010) nr 4, s. 520-545.

K a i s e r O., Der historische und der biblische König Saul (Teil II), ZAW 123(2011) nr 1, s. 1-14.

$\mathrm{K}$ a $1 \mathrm{i} \mathrm{m}$ i I., Reshaping of Ancient Israelite History in Chronicles, Eisenbrauns, Winona Lake 2005.

K a 1 i m i I., Starożytny historyk izraelski. Studium o Kronikarzu, jego epoce, miejscu działalności i dziele, Nomos, Kraków 2016.

K it te l R., Die Bücher der Chronik übersetzt und erklärt, GHAT 6.1, Vandenhoeck \& Ruprecht, Göttingen 1902.

$\mathrm{K} 1 \mathrm{e}$ in R., 1 Chronicles. A Commentary on 1Chronicles, HCHCB, Fortress Press, Minneapolis 2006.

Knierim R., $m^{\prime} l$, w: J enni E., Westermann C. (red.), Theological Lexicon of the Old Testament, t. 2, Kaiser Verlag, München 2004, s. 480-482.

K n o p p e r s G.N., 1Chronicles 1-29. A New Translation with Introduction and Commentary, AB 12A, Doubleday, New York 2004.

K n o p p e r s G.N., The Historical Study of the Monarchy: Developments and Detours, w: B a ke r D.W., A r n old B.T. (red.), The Face of the Old Testament Studies: A Survey of Contemporary Approaches, Baker, Grand Rapids 1999, s. 207-235.

L o r e n z in T., 1-2 Cronache. Nuova versione, introduzione e commento, Paoline Editoriali, Milano 2011. 
M c C a r thy D., Hero and Anti-Hero in 1Sam 13,2-14,46, w: t e n ż e (red.), Institution and Narrative. Collected Essays, AnBib 108, Roma 1985, s. 252-259.

M c Ke n zi e J., A Theology of the Old Testament, Doubleday, Garden City 1974.

M o s i s R., Untersuchungen zur Theologie des chronistischen Geschichtswerkes, FTS 92, Herder, Freiburg 1973.

Mü 11 e r R., Saul, the Charismatic King: Concepts of Political Leadership in 1Sam 11, w: Py schny K., Schulz S. (red.), Debating Authority. Concepts of Leadership in the Pentateuch and the Former Prophets, BZAW 507, de Gruyter, Berlin 2018, s. 262-287.

$\mathrm{N}$ a' a $\mathrm{m}$ a $\mathrm{n}$ N., Saul, Benjamin and the Emergence of "Biblical Israel" (Part I), ZAW 121(2009) nr 2, s. 211-224.

$\mathrm{Na}$ ' a m a n N., Saul, Benjamin and the Emergence of "Biblical Israel" (Part II), ZAW 121(2009) nr 3, s. 335-349.

$\mathrm{N}$ i c h o $1 \mathrm{~s}$ on S., Three Faces of Saul. An Intertextual Approach to Biblical Tragedy, JSOT.S 339, Sheffield Academic Press, Sheffield 2002.

Nihan C., Nocquet D., 1-2 Samuel, w: Römer T., Macchi J.D., $\mathrm{N}$ i h a n C. (red.), Introduction à l'Ancien Testament, MDB 45, Labor et fides, Genève 2004, s. 277-301.

N o 11 K., The Faces of David, JSOT.S 242, Sheffield Academic Press, Sheffield 1997.

P a y n e J., 1,2 Chronicles, EBC 4, Zondervan, Grand Rapids 1988.

$\mathrm{P}$ fe iffe r R., Introduction to the Old Testament, Harper \& Brothers, New York 1957.

P o p ov i c A., Saul's Fault in 1Sam 13,7b-15a. Why Has the First Israelite King Fallen? Antonianum 68/1993, s. 153-170.

P r it c h a rd J. (red.), Ancient Near Eastern Texts Relating to the Old Testament, Princeton University Press, Princeton 1969.

R ing g r e n H., $m^{\prime} l$, w: B o t t e rwe ck G., R ing g re n H., Fabry H., Theological Dictionary of the Old Testament, t. 8, Eerdmans, Grand Rapids 1997, s. 460-463.

S chäfer-Li ch t e n b e rge r C. (red.), Die Samuelbücher und die Deuteronomisten, BWANT 188, Kohlhammer, Stuttgart 2010.

S e g a 1 M., Between Bible and Rewritten Bible, w: H e n z e M. (red.), Biblical Interpretation at Qumran, Eerdmans, Grand Rapids 2005, s. 10-28.

S e $1 \mathrm{~m}$ a n M., Jerusalem in Chronicles, w: Hes s R., We $\mathrm{n} \mathrm{h}$ a m G. (red.), Zion City of Our God, Eerdmans, Grand Rapids 1999, s. 43-56.

Seters Van J., Creative Imitation in the Hebrew Bible, SR 29/2000, s. 395-409. 
S m e n d R., Die Entstehung des Alten Testaments, TW 1, W. Kohlhammer, Stuttgart 1978.

S m it h J., 1Chronicles: Focus on King David. A Commentary, Lulu.com 2016.

$\mathrm{S}$ t o e b e H., Das erste Buch Samuelis, KAT 8.1, Evangelische Verlag, Gütersloh 1973.

Th o m p s o n J., 1,2 Chronicles, NAC 9, Broadman \& Holman Publishers, Nashville 1994.

Tro n in a A., Pierwsza Księga Kronik, NKB 10.1, Edycja św. Pawła, Częstochowa 2015.

Trot te r J., Reading, Readers and Reading Readers Reading the Account of Saul's Death in 1Chronicles 10, w: Grah a m M., McKenzie S. (red.), The Chronicler as Author. Studies in Text and Texture, JSOT.S 263, Sheffield Academic Press, Sheffield 1999, s. 294-310.

Ve i j o l a T., Die ewige Dynastie. David und die Entstehung seiner Dynastie nach der deuteronomistischen Darstellung, AASF B 193, Suomalainen Tiedeakatemia, Helsinki 1975.

Ve i j o l a T., Das Königtum in der Beurteilung der deuteronomistischen Historiographie. Eine redaktionsgeschichtliche Untersuchung, AASF B 198, Suomalainen Tiedeakatemia, Helsinki 1977.

W a lv o o r d J., Z u ck R., The Bible Knowledge Commentary, Victor Books, New York 1983.

W e i s e r A., 1Samuel 15, ZAW 54/1936, s. 1-28.

We $1 \mathrm{ch}$ A., The Work of the Chronicler: Its Purpose and Its Date, SLBA, Oxford University Press, London 1938.

We $11 \mathrm{~h}$ a u s e n J., Prolegomena zur Geschichte Israels, G. Reiner, Berlin 1883.

$\mathrm{W}$ e $11 \mathrm{~h}$ a u s e n J., Prolegomena to the History of Ancient Israel, Peter Smith, Gloucester 1973.

W i 11 i a m s o n H., 1 and 2 Chronicles, NCBC, Eerdmans, Grand Rapids 1982.

W i 11 i T., Die Chronik als Auslegung: Untersuchungen zur literarischen Gestaltung der historischen Überlieferung Israels, FRLANT 106, Vandenhoeck \& Ruprecht, Göttingen 1972.

Y o n i c k Y., Rejection of Saul as King of Israel, Franciscan Printing, Jerusalem 1970.

$\mathrm{Z}$ a le w s k i S., The Purpose of the Story of the Death of Saul in 1Chronicles X, VT 39/1989, s. 449-467.

$\mathrm{Z}$ e n g e r E., Introduzione all'Antico Testamento, Editrice Queriniana, Brescia 2005.

Z s e n g e llé r J. (red.), Rewritten Bible after Fifty Years: Texts, Terms, or Techniques? A Last Dialogue with Geza Vermes, JSJ.S 166, Brill, Leiden 2013. 